\title{
Activation Energy and NBO Interaction Approaches to the Determination of the Relative Resonance Acceptor Strengths of CN, NO, COMe, $\mathrm{CHO}$ and NO2 Groups from the Ring-Opening of 1,2-Benzo-3-Carbomethoxycyclobutenes
}

Veejendra Yadav, Arpita Yadav

Submitted date: 06/06/2019 Posted date: 07/06/2019

Licence: CC BY-NC-ND 4.0

Citation information: Yadav, Veejendra; Yadav, Arpita (2019): Activation Energy and NBO Interaction Approaches to the Determination of the Relative Resonance Acceptor Strengths of CN, NO, COMe, CHO and NO2 Groups from the Ring-Opening of 1,2-Benzo-3-Carbomethoxycyclobutenes. ChemRxiv. Preprint.

The relative resonance-acceptor ability based on the activation energies for the outward ring-openings of 1,2-benzo-3-carbomethoxycyclobutenes bearing $\mathrm{CN}, \mathrm{NO}, \mathrm{COMe}, \mathrm{CHO}$ and $\mathrm{NO}_{2}$ as $\mathrm{C} 6$ and $\mathrm{C} 7$ substituents is different from that based on the $\mathrm{S}_{\mathrm{C} 3 \mathrm{C} 4}-\mathrm{p}^{*} \mathrm{C}_{1 \mathrm{C} 2}$ interactions in the inward opening transition structures. The differential activation energy $\left(\Delta \mathrm{G}^{\ddagger}\right)$ predicts outward ring-opening and, in contrast, the differential $\mathrm{S}_{\mathrm{C} 3 \mathrm{C} 4}{ }^{-\mathrm{p}^{*}} \mathrm{C} 1 \mathrm{C} 2$ interaction energy predicts inward opening, throughout. The relative resonance-acceptor ability estimated from the $\mathrm{s}_{\mathrm{C} 3 \mathrm{C} 4}{ }^{-\mathrm{p}^{*}} \mathrm{C} 1 \mathrm{C} 2$ interaction energies is more realistic than that from the activation energies.

File list (3)

manuscript06062019.docx (74.34 KiB)

view on ChemRxiv • download file manuscript06062019.pdf (467.21 KiB) view on ChemRxiv • download file 


\title{
Activation energy and NBO interaction approaches to the determination of the relative resonance acceptor strengths of $\mathrm{CN}, \mathrm{NO}, \mathrm{COMe}, \mathrm{CHO}$ and $\mathrm{NO}_{2}$ groups from the ring-opening of 1,2-benzo-3-carbomethoxycyclobutenes
}

\author{
Veejendra K. Yadav and Arpita Yadav ${ }^{\mathrm{b}}$

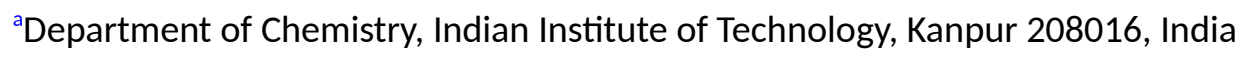 \\ ${ }^{\mathrm{b} D e p a r t m e n t}$ of Chemistry, University Institute of Engineering \& Technology, CSJM University, Kanpur 208024, \\ India
}

Abstract: The relative resonance-acceptor ability based on the activation energies for the outward ringopenings of 1,2-benzo-3-carbomethoxycyclobutenes bearing $\mathrm{CN}, \mathrm{NO}, \mathrm{COMe}, \mathrm{CHO}$ and $\mathrm{NO}_{2}$ as $\mathrm{C} 6$ and C7 substituents is different from that based on the ${ }^{0}{ }_{\mathrm{C}_{3} 4^{-}}{ }^{-}{ }^{*}{ }_{\mathrm{C} 1 \mathrm{C} 2}$ interactions in the inward opening transition structures. The differential activation energy $\left(\Delta \mathrm{G}^{\ddagger}\right)$ predicts outward ring-opening and, in contrast, the differential ${ }^{\circ}{ }_{\mathrm{C}_{34} 4^{-}}{ }^{*}{ }_{\mathrm{c} 1 \mathrm{c} 2}$ interaction energy predicts inward opening, throughout. The relative resonance-acceptor ability estimated from the ${ }^{0}{ }_{\mathrm{Csc}^{-}}{ }^{-}{ }^{*}{ }_{1122}$ interaction energies is more realistic than that from the activation energies.

Keywords: relative resonance-acceptor ability, 1,2-benzo-3-carbomethoxycyclobutenes, conrotatory ring-opening, torquoselectivity, transition structure, activation energy, NBO analysis 
Introduction: The effect of a C1-substituent on the efficacy of the conrotatory thermal ring-opening of a given 3-substituted cyclobutene (Scheme 1) was observed by Houk to be minimal; a donor substituent raised the activation energy slightly, and a powerful acceptor substituent slightly lowered it. ${ }^{1}$ This premise was lately used by $u^{2}$ as a strategic tool to estimate the relative resonance-acceptor ability of the functional groups $\mathrm{CN}$, NO, COMe, $\mathrm{CHO}$ and $\mathrm{NO}_{2}$ from $\mathrm{MP} 2 / 6-31+\mathrm{G}(\mathrm{d}, \mathrm{p})$ level quantum chemical calculations to discover that the relative acceptor ability based on the Gibbs' free energy of activation for outward opening $\Delta \mathrm{G}_{\text {out }}^{\ddagger}\left(\mathrm{CN}<\mathrm{NO}<\mathrm{NO}_{2}<\mathrm{COMe}<\mathrm{CHO}\right)$ was different from that based on the Gibbs' free energy of activation for inward opening $\Delta \mathrm{G}_{\text {in }}^{\ddagger}\left(\mathrm{CN}<\mathrm{NO}<\mathrm{CHO}<\mathrm{NO}_{2}<\mathrm{COMe}\right.$ ). It was also discovered that the relative acceptor ability from the NBO interactions in the outward opening transition structures was much the same as that from the inward opening transition structures. The relative acceptor ability from the ${ }^{\circ}{\mathrm{C} 3 \mathrm{C}^{-}}^{-}{ }^{*}{ }_{\mathrm{C}_{1 \mathrm{C} 2} \mathrm{NBO}} \mathrm{Ninteractions}$ was estimated to be $\mathrm{CN}<\mathrm{COMe}<\mathrm{CHO}$ $<\mathrm{NO}_{2}<\mathrm{NO}$, which is in accordance with the text book wisdom. ${ }^{3}$

Scheme 1. Conrotatory outward $(1 \rightarrow 2)$ and inward $(1 \rightarrow 3)$ openings of $1-\mathrm{R}-3-\mathrm{CO}_{2} \mathrm{Me}-\mathrm{cyclobutene}(\mathrm{R}=\mathrm{H}$, $\mathrm{CN}, \mathrm{NO}, \mathrm{COMe}, \mathrm{CHO}$ and $\mathrm{NO}_{2}$ )

The above study was warranted primarily because (a) $\mathrm{NO}_{2}$ and COMe were previously noted to possess, more or less, similar electron-accepting power based on the Taft $\sigma \mathrm{R}^{0}$ parameters and (b) $\mathrm{CHO}$ and NO, as C3-substituents on cyclobutene, were debated to be stronger acceptors than $\mathrm{CN}$, COMe and $\mathrm{NO}_{2}$ to align with the predicted ring-openings based on the differential energies of activation. ${ }^{1} 3$ $\mathrm{CO}_{2} \mathrm{Me}-\mathrm{cyclobutene}$ was predicted to open outward and it was considered vindicated from the experimentally observed predominantly outward opening of 1,2-benzo-3-carbomethoxycyclobutene. ${ }^{1}$ It is to be noted that the experimental results of the ring-openings of $3-\mathrm{CO}_{2} \mathrm{Me}-$ and $3-\mathrm{NO}_{2}-$ cyclobutenes are hitherto not reported. We have recently shown from the study of the NBO interactions that 1,2-benzo-3- $\mathrm{CO}_{2} \mathrm{Me}-$ cyclobutene and 1,2-benzo-3-CONMe - -cyclobutene opened 
inward faster than outward in an equilibrium process and that the outward opened product predominated because it was significantly more stable than the inward opened variant. ${ }^{4}$ We have also demonstrated that unlike the four-electron process in the ring-opening of 3-substituted cyclobutenes, the ring-opening in 1,2-benzo-3- $\mathrm{CO}_{2} \mathrm{Me}$-cyclobutene is an eight-electron process for the absence of the

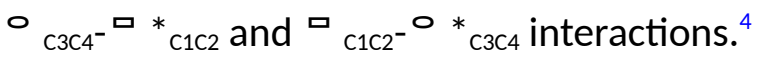

Scheme 2. Conrotatory outward $(4 \rightarrow 5$ and $7 \rightarrow 8$ ) and inward ( $4 \rightarrow 6$ and $7 \rightarrow 9$ ) openings of 6 - and 7-R1,2-benzo-3- $\mathrm{CO}_{2} \mathrm{Me}$-cyclobutenes $\left(\mathrm{R}=\mathrm{H}, \mathrm{CN}, \mathrm{NO}, \mathrm{COMe}, \mathrm{CHO}\right.$ and $\mathrm{NO}_{2}$ )

We wondered about the effect of resonance-acceptors located on the aromatic ring in 3- $\mathrm{CO}_{2} \mathrm{Me}-1,2-$ benzocyclobutene on the efficacy of ring-opening, with focus to explore whether (a) the acceptors lowered the energies of activation as they do for the opening of $3-\mathrm{CO}_{2} \mathrm{Me}-\mathrm{cyclobutenes}$ bearing the acceptors on $\mathrm{C} 1$ and (b) there existed an acceptable trend in the relative acceptor strengths of the chosen functional groups from the point of view of the energy of activation and also the NBO interaction energies. We chose to study the substrates bearing the resonance acceptors on C6 and C7 (Scheme 2). Substituents on C5 and C8 are likely to introduce the element of steric effects and, hence, such substrates were excluded from the present investigation.

Computational methods: The geometry optimizations of all the structures studied herein and the transition structure searches were carried out using the quantum chemical MP2 method at the 6$31+G(d, p)$ level of theory. ${ }^{5}$ The optimized structures were verified as minima or first order saddle 
points on their potential energy surfaces by harmonic vibrational frequency analysis. The Cartesian coordinates of the optimized structures and their Gibbs' free energies are given in the Supplementary Information.

Results and Discussion: The Gibbs' free energies of activation and the most relevant NBO interactions in the transition structures for the inward and outward openings are collected in Table 1. The absence of the ${ }^{{ }_{\mathrm{C}_{1 C 2}}}{ }^{\circ}{ }_{\mathrm{C}_{3 \mathrm{C} 4}}$ and ${ }^{\circ}{ }_{\mathrm{C3C4}^{-}}{ }^{a^{*}}{ }_{\mathrm{C}_{112} 2}$ interactions in both the transition structures (not shown) suggests eight-electron process. Further, while a comparison of the ${ }^{0}{ }_{\mathrm{Cзc}_{4}}^{-}{ }^{-}{ }^{*}$ co interaction energies suggests inward opening in all the instances, the differential activation energies call for outward opening. It is surprising to note that all the acceptors raised the activation energies of both the inward and outward ring-opening reactions in reference to the unsubstituted species $(R=H)$. This is in contrast to the lowering of activation energies of the reactions of $3-\mathrm{CO}_{2} \mathrm{Me}-$ cyclobutenes bearing the acceptors on $\mathrm{C} 1$.

Table 1. Gibbs' free energies of activation and the significant NBO interactions $(\mathrm{kcal} / \mathrm{mol})$ in the TSs for inward $(4 \rightarrow 6)$ and outward $(4 \rightarrow 5)$ openings ( ${ }^{\square}$ co and ${ }^{\square}{ }^{*}$ co correspond to $\mathrm{CO}_{2} \mathrm{Me}$ )

\begin{tabular}{|c|c|c|c|c|c|c|}
\hline \multirow[b]{2}{*}{$\mathrm{R}$} & \multirow[b]{2}{*}{$\Delta \mathrm{G}_{\text {in }}^{\ddagger}$} & \multirow[b]{2}{*}{$\Delta \mathrm{G}_{\text {out }}^{\ddagger}$} & \multicolumn{2}{|c|}{ inward TS $(4 \rightarrow 6)$} & \multicolumn{2}{|c|}{ outward TS $(4 \rightarrow 5)$} \\
\hline & & & $\begin{array}{l}\mathrm{C}_{\mathrm{CC} 4^{-}} \\
{ }^{*}{ }_{\mathrm{CO}}\end{array}$ & ${\text { 口 } \mathrm{CO}^{-}}^{\circ}{ }^{*}{ }_{\mathrm{C} 3 \mathrm{C} 4}$ & $\begin{array}{l}{ }_{\mathrm{C} 3 \mathrm{C}^{-}} \\
{ }^{*}{ }_{\mathrm{CO}}\end{array}$ & $\begin{array}{l}\mathrm{CO}^{-} \\
\mathrm{C}^{*}{ }_{\mathrm{C} 3 \mathrm{C} 4}\end{array}$ \\
\hline $\mathrm{H}$ & 37.65 & 35.60 & 71.03 & 0.84 & 38.27 & 4.73 \\
\hline $\mathrm{CN}$ & 38.62 & 36.31 & 67.99 & 0.81 & 36.72 & 4.77 \\
\hline $\mathrm{NO}^{a}$ & 38.90 & 36.52 & 69.17 & 0.76 & 37.73 & 4.67 \\
\hline $\mathrm{NO}^{b}$ & 38.11 & 35.80 & 67.93 & 0.76 & 36.46 & 4.70 \\
\hline $\mathrm{COMe}^{a}$ & 38.89 & 36.17 & 70.48 & 0.78 & 38.54 & 4.61 \\
\hline $\mathrm{COMe}^{b}$ & 38.57 & 36.53 & 69.61 & 0.79 & 37.22 & 4.74 \\
\hline $\mathrm{CHO}^{a}$ & 38.67 & 36.30 & 69.67 & 0.78 & 38.23 & 4.63 \\
\hline $\mathrm{CHO}^{b}$ & 37.99 & 35.94 & 68.69 & 0.78 & 36.82 & 4.74 \\
\hline $\mathrm{NO}_{2}$ & 38.59 & 36.27 & 67.71 & 0.79 & 36.76 & 4.75 \\
\hline
\end{tabular}

${ }^{\mathrm{a}}$ Torsion angle $5-6-\mathrm{C} / \mathrm{N}-\mathrm{O}=\sim 0.0$, ${ }^{\mathrm{b}}$ Torsion angle $5-6-\mathrm{C} / \mathrm{N}-\mathrm{O}=\sim 180.0 . \mathrm{NO}^{\mathrm{a}}$ is more stable than $\mathrm{NO}^{\mathrm{b}}$ by $0.30 \mathrm{kcal} / \mathrm{mol}$. COMe ${ }^{\mathrm{a}}$ is less stable than $\mathrm{COMe}^{\mathrm{b}}$ by $0.39 \mathrm{kcal} / \mathrm{mol} \mathrm{CHO}^{\mathrm{a}}$ is more stable than $\mathrm{CHO}^{\mathrm{b}}$ by $0.06 \mathrm{kcal} / \mathrm{mol}$. 
For the substrates bearing $\mathrm{NO}$, COMe and $\mathrm{CHO}$, there are two main conformers on allowing for resonance with the benzene ring. The torsion angle $5-6-\mathrm{C} / \mathrm{N}-\mathrm{O}$ is $0^{\circ}$ in the conformer $a$ and $180^{\circ}$ in the conformer $b$. The two conformers differ from each other by a small margin of energy, 0.06-0.39 $\mathrm{kcal} / \mathrm{mol}$, such that both exist under rapid equilibrium under the thermal conditions of the reaction. The $\pi_{\mathrm{C}_{2} 3}-\pi^{*}{ }_{\text {co }}$ interaction (not shown), which was previously suggested to provide for a stabilizing interaction to the ring-opening transition structure, ${ }^{1}$ is absent throughout. This suggests reactant-like transition structures.

The energy of activation $\left(\Delta G^{\ddagger}\right)$ supports outward opening throughout. Taking this energy into consideration, the relative resonance-acceptor strength turns out to be $\mathrm{NO}<\mathrm{CN}<\mathrm{CHO}<\mathrm{NO}_{2}<\mathrm{COMe}^{-}$ $<\mathrm{H}$ for the $a$ series of materials and $\mathrm{COMe}<\mathrm{CN}<\mathrm{NO}_{2}<\mathrm{CHO}<\mathrm{NO}<\mathrm{H}$ for the $b$ series of materials. Both the series are significantly different from each other, the substrate with no substituent having the lowest activation energy being the common feature. That the $\mathrm{H}$ is the strongest acceptor among the groups studied herein casts aspersions on the applicability of the differential activation energy to torquoselectivity prediction and also the estimation of the resonance-acceptor strength.

The less the ${ }^{\text {ring }^{-}}{ }^{\circ *}{ }_{\text {сзс4 }}$ interaction (not measured as such by the NBO analysis) for the larger resonance-acceptor strength of the substituent (which lowers the ${ }^{{ }^{2}}{ }_{\text {ring }}$ ), the lower shall be ${ }^{\circ}$ cзс4. This, in turn, will result in lower ${ }^{\circ} \mathrm{Csc4}^{-}{ }^{-*}{ }_{\text {co }}$ interaction. Thus, the lower the ${ }^{0} \mathrm{C3C4}^{-}{ }^{*}{ }_{\mathrm{co}}$ interaction, the higher will be the resonance-acceptor strength of the substituent. Going by this premise and considering the inward ring-opening, the resonance-acceptor strength turns out to be $\mathrm{H}<\mathrm{COMe}<\mathrm{CHO}$ $<\mathrm{NO}<\mathrm{CN}<\mathrm{NO}_{2}$ for the $a$ series of materials and $\mathrm{H}<\mathrm{COMe}<\mathrm{CHO}<\mathrm{CN}<\mathrm{NO}<\mathrm{NO}_{2}$ for the $b$ series of materials. Except for the interchange in the positions of $\mathrm{NO}$ and $\mathrm{CN}$, the two series are the same. From both the series, the relative acceptor strength of the COMe, $\mathrm{CHO}$ and $\mathrm{NO}_{2}$ groups is $\mathrm{COMe}<\mathrm{CHO}<$ $\mathrm{NO}_{2}$, which is in excellent agreement with the general text book wisdom. ${ }^{3}$ The weakest point of both the relative series is probably the exhibit that $\mathrm{CN}$ has better acceptor strength than both COMe and $\mathrm{CHO}$, a point that is difficult for a chemist to agree with. 
Table 2. Gibbs' free energies of activation and the significant NBO interactions $(\mathrm{kcal} / \mathrm{mol})$ in the TSs for inward $(7 \rightarrow 9)$ and outward $(\mathbf{7} \rightarrow \mathbf{8})$ openings ( ${ }^{\square}$ co and ${ }^{\square}{ }^{*}$ co correspond to $\left.\mathrm{CO}_{2} \mathrm{Me}\right)$

\begin{tabular}{|c|c|c|c|c|c|c|}
\hline \multirow[b]{2}{*}{$\mathrm{R}$} & \multirow[b]{2}{*}{$\Delta \mathrm{G}_{\mathrm{in}}^{\ddagger}$} & \multirow[b]{2}{*}{$\Delta \mathrm{G}_{\text {out }}^{\ddagger}$} & \multicolumn{2}{|c|}{ inward TS $(7 \rightarrow 9)$} & \multicolumn{2}{|c|}{ outward TS $(7 \rightarrow \mathbf{8})$} \\
\hline & & & $\begin{array}{l}\mathrm{C}_{\mathrm{CC} 4^{-}} \\
{ }^{*}{ }_{\mathrm{CO}}\end{array}$ & ${ }^{\circ} \mathrm{CO}^{-}{ }^{\circ}{ }^{*}{ }_{\mathrm{C} 3 \mathrm{C} 4}$ & $\begin{array}{l}{ }_{\mathrm{C} 3 \mathrm{C} 4^{-}} \\
\text {口 }{ }^{*}{ }_{\mathrm{CO}}\end{array}$ & $\begin{array}{l}\text { 口 } \mathrm{CO}^{-} \\
0^{*}{ }_{\mathrm{C} 3 \mathrm{C} 4}\end{array}$ \\
\hline $\mathrm{H}$ & 37.65 & 35.60 & 71.03 & 0.84 & 38.27 & 4.73 \\
\hline $\mathrm{CN}$ & 37.98 & 36.08 & 66.45 & 0.94 & 35.10 & 5.37 \\
\hline $\mathrm{NO}^{a}$ & 38.04 & 35.98 & 66.17 & 1.03 & 35.88 & 5.16 \\
\hline $\mathrm{NO}^{b}$ & 37.34 & 35.27 & 65.23 & 0.98 & 34.93 & 5.09 \\
\hline $\mathrm{COMe}^{a}$ & 37.83 & 36.22 & 67.78 & 0.98 & 36.26 & 5.16 \\
\hline $\mathrm{COMe}^{b}$ & 37.74 & 35.38 & 67.97 & 0.94 & 36.76 & 4.85 \\
\hline $\mathrm{CHO}^{a}$ & 37.94 & 36.14 & 67.05 & 1.00 & 36.06 & 5.17 \\
\hline $\mathrm{CHO}^{b}$ & 37.43 & 35.08 & 67.89 & 0.95 & 36.05 & 4.92 \\
\hline $\mathrm{NO}_{2}$ & 37.58 & 35.52 & 65.34 & 0.98 & 34.95 & 5.19 \\
\hline
\end{tabular}

${ }^{\mathrm{a}}$ Torsion angle $5-6-\mathrm{C} / \mathrm{N}-\mathrm{O}=\sim 0.0 ;{ }^{\mathrm{b}}$ Torsion angle $5-6-\mathrm{C} / \mathrm{N}-\mathrm{O}=\sim 180.0$; $\mathrm{NO}^{\mathrm{a}}$ is more stable than $\mathrm{NO}^{\mathrm{b}}$ by $0.31 \mathrm{kcal} / \mathrm{mol}$. COMe ${ }^{\mathrm{a}}$ is less stable than $\mathrm{COMe}^{\mathrm{b}}$ by $0.26 \mathrm{kcal} / \mathrm{mol}^{\mathrm{CHO}} \mathrm{CH}^{\mathrm{a}}$ is more stable than $\mathrm{CHO}^{\mathrm{b}}$ by $0.20 \mathrm{kcal} / \mathrm{mol}$.

We now turn to 7-R-1,2-benzo-3- $\mathrm{CO}_{2} \mathrm{Me}-$-cyclobutene and explore the ring-opening features in the context of activation energies and NBO interaction, as above. The relevant data for the inward and outward opening transition structures are collected in Table 2. Like 6-R-1,2-benzo-3- $\mathrm{CO}_{2} \mathrm{Me}-$ cyclobutene, the outward opening is favored over the inward opening from the differential activation energies and the inward opening from the differential ${ }^{\circ} \mathrm{cзc}_{4^{-}}{ }^{*}$ co interactions. The relative acceptor strength form the consideration of the activation energies for outward opening is $\mathrm{COMe}<\mathrm{CHO}<\mathrm{CN}<$ $\mathrm{NO}<\mathrm{H}<\mathrm{NO}_{2}$ for the $a$ series of materials and $\mathrm{CN}<\mathrm{H}<\mathrm{NO}_{2}<\mathrm{COMe}<\mathrm{NO}<\mathrm{CHO}$ for the $b$ series materials. Other than being very different from each other, the order looks suspicious. How could $\mathrm{H}$ ever be a more powerful acceptor than even CN? The relative acceptor order from the NBO interactions in the inward opening transition structures is $\mathrm{H}<\mathrm{COMe}<\mathrm{CHO}<\mathrm{CN}<\mathrm{NO}<\mathrm{NO}_{2}$ for both the series of materials. This order is more sensible than the one based on the activation energy above. The $\mathrm{H}$ is the least powerful acceptor and $\mathrm{NO}_{2}$ the most powerful among the groups studied herein. The 
$\mathrm{CN}$ group here as well shows up to be a better acceptor than the COMe and $\mathrm{CHO}$ groups. The relative order of the acceptor strengths of the prominent groups $\mathrm{COMe}, \mathrm{CHO}$ and $\mathrm{NO}_{2}$ remains, however, unchanged from $\mathrm{COMe}<\mathrm{CHO}<\mathrm{NO}_{2}{ }^{3}$

Conclusion: It has been shown that the performance of the NBO approach to the prediction of the torquoselectivity of the ring-opening of 1,2-benzo-3- $\mathrm{CO}_{2} \mathrm{Me}-\mathrm{cyclobutenes}$ bearing substituents on the aromatic ring and also the estimation of the relative resonance-acceptor strengths of the substituents is superior to that of the activation energy approach. The relative resonance-acceptor strength of the common functional groups $\mathrm{COMe}, \mathrm{CHO}$ and $\mathrm{NO}_{2}$ estimated from the $\mathrm{NBO}$ approach is $\mathrm{COMe}<\mathrm{CHO}<$ $\mathrm{NO}_{2}$, which has general acceptability. Two important points, however, must be noted: (a) the present study recognizes $\mathrm{CN}$ as a better acceptor than $\mathrm{COMe}$ and $\mathrm{CHO}$ requires attention and (b) the relative acceptor strength estimated from the NBO study of the substituted 1,2-benzo-3- $\mathrm{CO}_{2} \mathrm{Me}$-cyclobutenes $\left(\right.$ COMe $\left.<\mathrm{CHO}<\mathrm{CN}<\mathrm{NO}<\mathrm{NO}_{2}\right)$ is different the one estimated previously ${ }^{2}$ from the study of the 1substituted-3- $\mathrm{CO}_{2}$ Me-cyclobutenes ( $\left.\mathrm{CN}<\mathrm{COMe}<\mathrm{CHO}<\mathrm{NO}_{2}<\mathrm{NO}\right)$.

\section{ASSOCIATED CONTENT}

\section{Supporting Information}

Cartesian coordinates of the optimized substrates, transition structures and Gibbs' free energies (PDF)

\section{Author Information}

\section{Corresponding Authors}

vijendra@iitk.ac.in

arpitayadav@yahoo.co.in

\section{Notes}

The authors declare no competing financial interest.

ACKNOWLEDGEMENTS 
VKY thanks the Council of Scientific \& Industrial Research and Department of Science \& Technology, Government of India, for funding. VKY also acknowledges the generous allocation of time on HPC2013 series of supercomputers by the Computer Center of IIT Kanpur.

\section{REFERENCES AND NOTES}

1. Substituent effects on rates and stereoselectivities of conrotatory electrocyclic reactions of cyclobutenes. A theoretical study, Niwayama, S.; Kallel, E. A.; Spellmeyer, D. C.; Sheu, C.; Houk, K. N. J. Org. Chem.1996, 61, 2813-2825.

2. On the relative resonance-acceptor abilities of $\mathrm{CN}, \mathrm{NO}, \mathrm{COMe}, \mathrm{CHO}$ and $\mathrm{NO}_{2}$ groups, Yadav, V. K.; Yadav, A. (2019): ChemRxiv. https://doi.org/10.26434/chemrxiv.8081945.v1

3. "Nitro is the most powerful of the common groups and thereafter the series follows the approximate order $\mathrm{NO}_{2}>\mathrm{COR}>\mathrm{SO}_{2} \mathrm{R}>\mathrm{CO}_{2} \mathrm{R}>\mathrm{CN}>\mathrm{C}_{6} \mathrm{H}_{5}$." See: W. Carruthers in Some Modern Methods of Organic synthesis, Cambridge University Press, $3^{\text {rd }}$ Ed, $\mathrm{p} 1$.

4. On the Conrotatory Ring Opening of 3-Carbomethoxycyclobutene vis-a-vis 3-Carbomethoxy-1,2Benzocyclobutene and the Predominant Inward Opening of 3-Dimethylaminocarbonyl-1,2-Benzocyclobutene, Yadav, V. K.; Prasad, D. L. $\quad$ V. $\quad$ K.; Yadav, A.; Rao, M. L. N. (2018): ChemRxiv. https://doi.org/10.26434/chemrxiv.7094003.v1

5. Gaussian 09, Revision B.01, Frisch, M. J.; Trucks, G. W.; Schlegel, H. B.; Scuseria, G. E.; Robb, M. A.; Cheeseman, J. R.; Scalmani, G.; Barone, V.; Mennucci, B.; Peterson, G. A.; Nakatsuji, H.; Caricato, M.; Li, X.; Hratchian, H. P.; Izmaylov, A. F.; Bloino, J.; Zheng, G.; Sonnenberg, J. L.; Hada, M.; Ehara, M.; Toyota, K.; Fukuda, R.; Hasegawa, J.; Ishida, M.; Nakajima,T.; Honda, Y.; Kitao, O.; Nakai, H.; Vreven, T.; Montgomery, Jr., J. A.; Peralta, J. E.; Ogliaro, F.; Bearpark, M.; Heyd, J. J.; Brothers, E.; Kudin,K. N.; Staroverov, V. N.; Keith, T.; Kobayashi, R.; Normand, J.; Raghavachari, K.; Rendell, A.; Burant, J. C.; Iyengar, S. S.; Tomasi, J.; Cossi, M.; Rega, N.; Millam, J. M.; Klene, M.; Knox, J. E.; Cross, J. B.; Bakken, V.; Adamo, C.; Jaramillo, J.; Gomperts, R.; Stratmann, R. E.; Yazyev, O.; Austin, A. J.; Cammi, R.; Pomelli, C.; Ochterski, J. W.; Martin, R. L.; Morokuma, K.; Zakrzewski, V. G.; Voth, G. A.; Salvador, P.; Dannenberg, J. J.; Dapprich, S.; Daniels, A. D.; Farkas, O.; Foresman, J. B.; Ortiz, J. V.; Cioslowski, J.; Fox, D. J. Gaussian, Inc., Wallingford CT, 2010. 


\title{
Activation energy and NBO interaction approaches to the determination of the relative resonance acceptor strengths of $\mathrm{CN}, \mathrm{NO}, \mathrm{COMe}, \mathrm{CHO}$ and $\mathrm{NO}_{2}$ groups from the ring-opening of 1,2-benzo-3-carbomethoxycyclobutenes
}

\author{
Veejendra K. Yadav and Arpita Yadav ${ }^{\mathrm{b}}$ \\ aDepartment of Chemistry, Indian Institute of Technology, Kanpur 208016, India

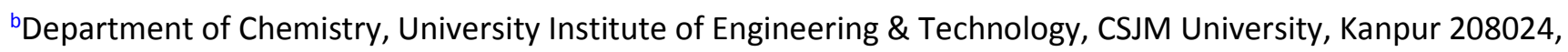 \\ India

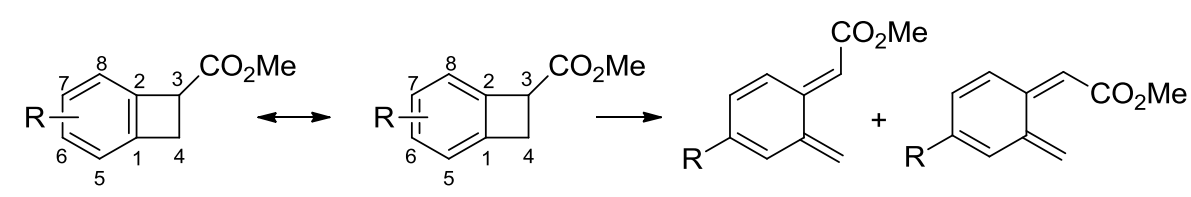 \\ Abstract: The relative resonance-acceptor ability based on the activation energies for the outward \\ ring-openings of 1,2-benzo-3-carbomethoxycyclobutenes bearing $\mathrm{CN}, \mathrm{NO}, \mathrm{COMe}, \mathrm{CHO}$ and $\mathrm{NO}_{2}$ as $\mathrm{C6}$ \\ and $\mathrm{C7}$ substituents is different from that based on the $\sigma_{\mathrm{c} 3 \mathrm{C}_{4}-} \pi^{*}{ }_{\mathrm{c} 1 \mathrm{c} 2}$ interactions in the inward opening \\ transition structures. The differential activation energy $\left(\Delta G^{\ddagger}\right)$ predicts outward ring-opening and, in \\ contrast, the differential $\sigma_{c_{3} 4}-\pi^{*}{ }_{\mathrm{c} 1 \mathrm{C}_{2}}$ interaction energy predicts inward opening, throughout. The

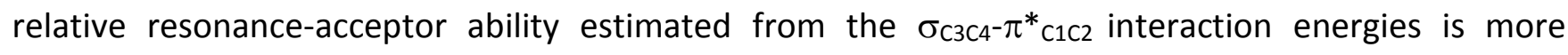 \\ realistic than that from the activation energies.
}

Keywords: relative resonance-acceptor ability, 1,2-benzo-3-carbomethoxycyclobutenes, conrotatory ring-opening, torquoselectivity, transition structure, activation energy, NBO analysis 
Introduction: The effect of a C1-substituent on the efficacy of the conrotatory thermal ring-opening of a given 3-substituted cyclobutene (Scheme 1) was observed by Houk to be minimal; a donor substituent raised the activation energy slightly, and a powerful acceptor substituent slightly lowered it. ${ }^{1}$ This premise was lately used by $u^{2}$ as a strategic tool to estimate the relative resonance-acceptor ability of the functional groups $\mathrm{CN}, \mathrm{NO}, \mathrm{COMe}, \mathrm{CHO}$ and $\mathrm{NO}_{2}$ from $\mathrm{MP} 2 / 6-31+\mathrm{G}(\mathrm{d}, \mathrm{p})$ level quantum chemical calculations to discover that the relative acceptor ability based on the Gibbs' free energy of activation for outward opening $\Delta \mathrm{G}^{\ddagger}$ out $\left(\mathrm{CN}<\mathrm{NO}<\mathrm{NO}_{2}<\mathrm{COMe}<\mathrm{CHO}\right)$ was different from that based on the Gibbs' free energy of activation for inward opening $\Delta \mathrm{G}^{\ddagger}{ }_{\text {in }}\left(\mathrm{CN}<\mathrm{NO}<\mathrm{CHO}<\mathrm{NO}_{2}<\mathrm{COMe}\right)$. It was also discovered that the relative acceptor ability from the NBO interactions in the outward opening transition structures was much the same as that from the inward opening transition structures. The relative acceptor ability from the $\sigma_{\mathrm{C} 3 \mathrm{C}_{4}-} \pi^{*}{ }_{\mathrm{C} 1 \mathrm{C} 2} \mathrm{NBO}$ interactions was estimated to be $\mathrm{CN}$ $<\mathrm{COMe}<\mathrm{CHO}<\mathrm{NO}_{2}<\mathrm{NO}$, which is in accordance with the text book wisdom. ${ }^{3}$

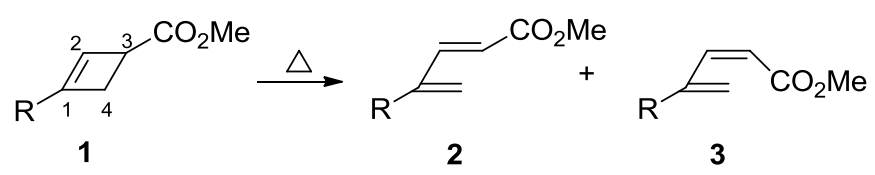

Scheme 1. Conrotatory outward $(\mathbf{1} \rightarrow \mathbf{2})$ and inward $(\mathbf{1} \rightarrow \mathbf{3})$ openings of $1-\mathrm{R}-3-\mathrm{CO}_{2} \mathrm{Me}$-cyclobutene $(\mathrm{R}=$ $\mathrm{H}, \mathrm{CN}, \mathrm{NO}, \mathrm{COMe}, \mathrm{CHO}$ and $\mathrm{NO}_{2}$ )

The above study was warranted primarily because (a) $\mathrm{NO}_{2}$ and COMe were previously noted to possess, more or less, similar electron-accepting power based on the Taft $\sigma \mathrm{R}^{0}$ parameters and (b) $\mathrm{CHO}$ and NO, as C3-substituents on cyclobutene, were debated to be stronger acceptors than $\mathrm{CN}, \mathrm{COMe}$ and $\mathrm{NO}_{2}$ to align with the predicted ring-openings based on the differential energies of activation. ${ }^{1} 3$ $\mathrm{CO}_{2} \mathrm{Me}-\mathrm{cyclobutene}$ was predicted to open outward and it was considered vindicated from the experimentally observed predominantly outward opening of 1,2-benzo-3-carbomethoxycyclobutene. ${ }^{1}$ It is to be noted that the experimental results of the ring-openings of $3-\mathrm{CO}_{2} \mathrm{Me}-$ and $3-\mathrm{NO}_{2}-$ 
cyclobutenes are hitherto not reported. We have recently shown from the study of the NBO interactions that 1,2-benzo-3- $\mathrm{CO}_{2} \mathrm{Me}$-cyclobutene and 1,2-benzo-3-CONMe - -cyclobutene opened inward faster than outward in an equilibrium process and that the outward opened product predominated because it was significantly more stable than the inward opened variant. ${ }^{4}$ We have also demonstrated that unlike the four-electron process in the ring-opening of 3-substituted cyclobutenes, the ring-opening in 1,2-benzo-3- $\mathrm{CO}_{2} \mathrm{Me}$-cyclobutene is an eight-electron process for the absence of the $\sigma_{\mathrm{c} 3 \mathrm{c}_{4}-} \pi^{*}{ }_{\mathrm{c} 1 \mathrm{c} 2}$ and $\pi_{\mathrm{C} 1 \mathrm{c} 2}-\sigma^{*}{ }_{\mathrm{c} 3 \mathrm{c} 4}$ interactions. ${ }^{4}$
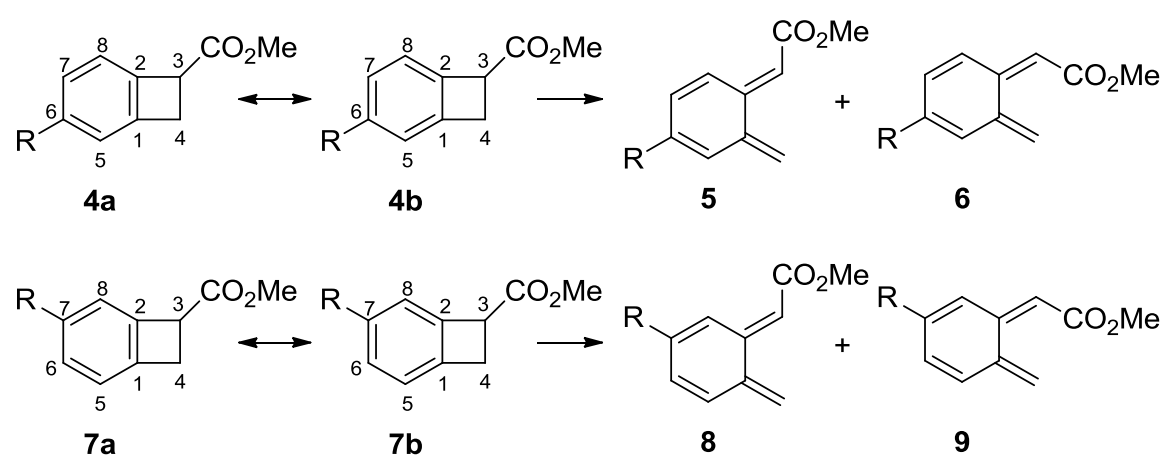

Scheme 2. Conrotatory outward $(4 \rightarrow 5$ and $7 \rightarrow 8)$ and inward $(4 \rightarrow 6$ and $7 \rightarrow 9)$ openings of 6 - and $7-R-$ 1,2-benzo-3- $\mathrm{CO}_{2}$ Me-cyclobutenes ( $\mathrm{R}=\mathrm{H}, \mathrm{CN}, \mathrm{NO}, \mathrm{COMe}, \mathrm{CHO}$ and $\mathrm{NO}_{2}$ )

We wondered about the effect of resonance-acceptors located on the aromatic ring in 3- $\mathrm{CO}_{2} \mathrm{Me}-1,2-$ benzocyclobutene on the efficacy of ring-opening, with focus to explore whether (a) the acceptors lowered the energies of activation as they do for the opening of 3- $\mathrm{CO}_{2} \mathrm{Me}$-cyclobutenes bearing the acceptors on $\mathrm{C} 1$ and (b) there existed an acceptable trend in the relative acceptor strengths of the chosen functional groups from the point of view of the energy of activation and also the NBO interaction energies. We chose to study the substrates bearing the resonance acceptors on C6 and C7 (Scheme 2). Substituents on C5 and C8 are likely to introduce the element of steric effects and, hence, such substrates were excluded from the present investigation. 
Computational methods: The geometry optimizations of all the structures studied herein and the transition structure searches were carried out using the quantum chemical MP2 method at the 6$31+G(d, p)$ level of theory. ${ }^{5}$ The optimized structures were verified as minima or first order saddle points on their potential energy surfaces by harmonic vibrational frequency analysis. The Cartesian coordinates of the optimized structures and their Gibbs' free energies are given in the Supplementary Information.

Results and Discussion: The Gibbs' free energies of activation and the most relevant NBO interactions in the transition structures for the inward and outward openings are collected in Table 1 . The absence of the $\pi_{\mathrm{C} 1 C 2^{-}} \sigma^{*}{ }_{\mathrm{C3} 34}$ and $\sigma_{\mathrm{C} 3 \mathrm{C}_{4}-} \pi^{*}{ }_{\mathrm{C} 1 \mathrm{C2} 2}$ interactions in both the transition structures (not shown) suggests eight-electron process. Further, while a comparison of the $\sigma_{\mathrm{c} 3 c_{4}-\pi^{*}}$ co interaction energies suggests inward opening in all the instances, the differential activation energies call for outward opening. It is surprising to note that all the acceptors raised the activation energies of both the inward and outward ring-opening reactions in reference to the unsubstituted species $(R=H)$. This is in contrast to the lowering of activation energies of the reactions of 3- $\mathrm{CO}_{2} \mathrm{Me}-\mathrm{cyclobutenes}$ bearing the acceptors on $\mathrm{C} 1$.

Table 1. Gibbs' free energies of activation and the significant NBO interactions ( $\mathrm{kcal} / \mathrm{mol})$ in the TSs for inward $(\mathbf{4} \rightarrow \mathbf{6})$ and outward $(\mathbf{4} \rightarrow \mathbf{5})$ openings ( $\pi_{\mathrm{co}}$ and $\pi^{*}$ co correspond to $\mathrm{CO}_{2} \mathrm{Me}$ )

\begin{tabular}{|c|c|c|c|c|c|c|}
\hline \multirow[b]{2}{*}{$\mathrm{R}$} & \multirow[b]{2}{*}{$\Delta \mathrm{G}^{*}{ }_{\text {in }}$} & \multirow[b]{2}{*}{$\Delta \mathrm{G}^{*}$ out } & \multicolumn{2}{|c|}{ inward TS $(4 \rightarrow 6)$} & \multicolumn{2}{|c|}{ outward TS $(\mathbf{4} \rightarrow 5)$} \\
\hline & & & $\sigma_{\mathrm{C} 3 \mathrm{C} 4}-\pi^{*}{ }_{\mathrm{CO}}$ & $\pi_{\mathrm{CO}}-\sigma^{*}{ }_{\mathrm{C} 3 \mathrm{C} 4}$ & $\sigma_{\mathrm{C} 3 \mathrm{C} 4}-\pi^{*}{ }_{\mathrm{CO}}$ & $\pi_{\mathrm{CO}-} \sigma^{*}{ }_{\mathrm{C} 3 \mathrm{C} 4}$ \\
\hline $\mathrm{H}$ & 37.65 & 35.60 & 71.03 & 0.84 & 38.27 & 4.73 \\
\hline $\mathrm{CN}$ & 38.62 & 36.31 & 67.99 & 0.81 & 36.72 & 4.77 \\
\hline $\mathrm{NO}^{a}$ & 38.90 & 36.52 & 69.17 & 0.76 & 37.73 & 4.67 \\
\hline $\mathrm{NO}^{b}$ & 38.11 & 35.80 & 67.93 & 0.76 & 36.46 & 4.70 \\
\hline $\mathrm{COMe}^{a}$ & 38.89 & 36.17 & 70.48 & 0.78 & 38.54 & 4.61 \\
\hline $\mathrm{COMe}^{b}$ & 38.57 & 36.53 & 69.61 & 0.79 & 37.22 & 4.74 \\
\hline $\mathrm{CHO}^{a}$ & 38.67 & 36.30 & 69.67 & 0.78 & 38.23 & 4.63 \\
\hline $\mathrm{CHO}^{b}$ & 37.99 & 35.94 & 68.69 & 0.78 & 36.82 & 4.74 \\
\hline
\end{tabular}




\begin{tabular}{|l|l|l|l|l|l|l|}
\hline $\mathrm{NO}_{2}$ & 38.59 & 36.27 & 67.71 & 0.79 & 36.76 & 4.75 \\
\hline
\end{tabular}

${ }^{\mathrm{a}}$ Torsion angle $5-6-\mathrm{C} / \mathrm{N}-\mathrm{O}=\sim 0.0,{ }^{\mathrm{b}}$ Torsion angle $5-6-\mathrm{C} / \mathrm{N}-\mathrm{O}=\sim 180.0 . \mathrm{NO}^{\mathrm{a}}$ is more stable than $\mathrm{NO}^{\mathrm{b}}$ by $0.30 \mathrm{kcal} / \mathrm{mol}$. COMe is less stable than $\mathrm{COMe}^{\mathrm{b}}$ by $0.39 \mathrm{kcal} / \mathrm{mol}^{\mathrm{CHO}} \mathrm{CH}^{\mathrm{a}}$ is more stable than $\mathrm{CHO}^{\mathrm{b}}$ by $0.06 \mathrm{kcal} / \mathrm{mol}$.

For the substrates bearing $\mathrm{NO}, \mathrm{COMe}$ and $\mathrm{CHO}$, there are two main conformers on allowing for resonance with the benzene ring. The torsion angle $5-6-\mathrm{C} / \mathrm{N}-\mathrm{O}$ is $0^{\circ}$ in the conformer $a$ and $180^{\circ}$ in the conformer $b$. The two conformers differ from each other by a small margin of energy, $0.06-0.39$ $\mathrm{kcal} / \mathrm{mol}$, such that both exist under rapid equilibrium under the thermal conditions of the reaction. The $\pi_{\mathrm{C} 2 \mathrm{C} 3}-\pi^{*}$ co interaction (not shown), which was previously suggested to provide for a stabilizing interaction to the ring-opening transition structure, ${ }^{1}$ is absent throughout. This suggests reactant-like transition structures.

The energy of activation $\left(\Delta \mathrm{G}^{\ddagger}\right)$ supports outward opening throughout. Taking this energy into consideration, the relative resonance-acceptor strength turns out to be $\mathrm{NO}<\mathrm{CN}<\mathrm{CHO}<\mathrm{NO}_{2}<\mathrm{COMe}^{-}$ $<\mathrm{H}$ for the $a$ series of materials and $\mathrm{COMe}<\mathrm{CN}<\mathrm{NO}_{2}<\mathrm{CHO}<\mathrm{NO}<\mathrm{H}$ for the $b$ series of materials. Both the series are significantly different from each other, the substrate with no substituent having the lowest activation energy being the common feature. That the $\mathrm{H}$ is the strongest acceptor among the groups studied herein casts aspersions on the applicability of the differential activation energy to torquoselectivity prediction and also the estimation of the resonance-acceptor strength.

The less the $\pi_{\text {ring }}-\sigma^{*}$ сзс4 interaction (not measured as such by the NBO analysis) for the larger

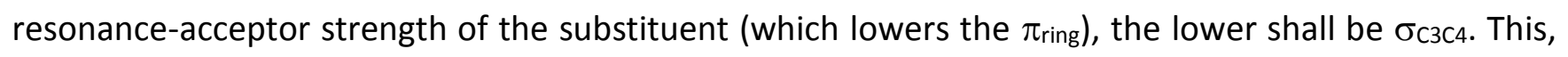
in turn, will result in lower $\sigma_{\mathrm{C} 3 \mathrm{C}_{4}-} \pi^{*} \mathrm{co}$ interaction. Thus, the lower the $\sigma_{\mathrm{C} 3 \mathrm{C}_{4}-} \pi^{*}{ }_{\mathrm{co}}$ interaction, the higher will be the resonance-acceptor strength of the substituent. Going by this premise and considering the inward ring-opening, the resonance-acceptor strength turns out to be $\mathrm{H}<\mathrm{COMe}<\mathrm{CHO}<\mathrm{NO}<\mathrm{CN}<$ $\mathrm{NO}_{2}$ for the $a$ series of materials and $\mathrm{H}<\mathrm{COMe}<\mathrm{CHO}<\mathrm{CN}<\mathrm{NO}<\mathrm{NO}_{2}$ for the $b$ series of materials. Except for the interchange in the positions of NO and CN, the two series are the same. From both the series, the relative acceptor strength of the COMe, $\mathrm{CHO}$ and $\mathrm{NO}_{2}$ groups is $\mathrm{COMe}<\mathrm{CHO}<\mathrm{NO}_{2}$, which 
is in excellent agreement with the general text book wisdom. ${ }^{3}$ The weakest point of both the relative series is probably the exhibit that $\mathrm{CN}$ has better acceptor strength than both COMe and $\mathrm{CHO}$, a point that is difficult for a chemist to agree with.

Table 2. Gibbs' free energies of activation and the significant NBO interactions ( $\mathrm{kcal} / \mathrm{mol})$ in the TSs for inward $(\mathbf{7} \rightarrow \mathbf{9})$ and outward $(\mathbf{7} \rightarrow \mathbf{8})$ openings ( $\pi_{\mathrm{co}}$ and $\pi^{*}$ co correspond to $\mathrm{CO}_{2} \mathrm{Me}$ )

\begin{tabular}{|c|c|c|c|c|c|c|}
\hline \multirow[b]{2}{*}{$\mathrm{R}$} & \multirow[b]{2}{*}{$\Delta \mathrm{G}^{\ddagger}$ in } & \multirow[b]{2}{*}{$\Delta \mathrm{G}^{\ddagger}$ out } & \multicolumn{2}{|c|}{ inward TS $(\mathbf{7} \rightarrow \mathbf{9})$} & \multicolumn{2}{|c|}{ outward TS $(7 \rightarrow 8)$} \\
\hline & & & $\sigma_{\mathrm{C} 3 \mathrm{C} 4}-\pi^{*}{ }_{\mathrm{CO}}$ & $\pi_{\mathrm{CO}-} \sigma^{*}{ }_{\mathrm{C} 3 \mathrm{C} 4}$ & $\sigma_{\mathrm{C} 3 \mathrm{C} 4}-\pi^{*}{ }_{\mathrm{CO}}$ & $\pi_{\mathrm{CO}}-\sigma^{*}{ }_{\mathrm{C} 3 \mathrm{C} 4}$ \\
\hline $\mathrm{H}$ & 37.65 & 35.60 & 71.03 & 0.84 & 38.27 & 4.73 \\
\hline $\mathrm{CN}$ & 37.98 & 36.08 & 66.45 & 0.94 & 35.10 & 5.37 \\
\hline $\mathrm{NO}^{a}$ & 38.04 & 35.98 & 66.17 & 1.03 & 35.88 & 5.16 \\
\hline $\mathrm{NO}^{b}$ & 37.34 & 35.27 & 65.23 & 0.98 & 34.93 & 5.09 \\
\hline $\mathrm{COMe}^{a}$ & 37.83 & 36.22 & 67.78 & 0.98 & 36.26 & 5.16 \\
\hline $\mathrm{COMe}^{b}$ & 37.74 & 35.38 & 67.97 & 0.94 & 36.76 & 4.85 \\
\hline $\mathrm{CHO}^{a}$ & 37.94 & 36.14 & 67.05 & 1.00 & 36.06 & 5.17 \\
\hline $\mathrm{CHO}^{b}$ & 37.43 & 35.08 & 67.89 & 0.95 & 36.05 & 4.92 \\
\hline $\mathrm{NO}_{2}$ & 37.58 & 35.52 & 65.34 & 0.98 & 34.95 & 5.19 \\
\hline
\end{tabular}

${ }^{\mathrm{a}}$ Torsion angle $5-6-\mathrm{C} / \mathrm{N}-\mathrm{O}=\sim 0.0$; ${ }^{\mathrm{b}}$ Torsion angle $5-6-\mathrm{C} / \mathrm{N}-\mathrm{O}=\sim 180.0$; $\mathrm{NO}^{\mathrm{a}}$ is more stable than $\mathrm{NO}^{\mathrm{b}}$ by $0.31 \mathrm{kcal} / \mathrm{mol}$. COMe is less stable than $\mathrm{COMe}^{\mathrm{b}}$ by $0.26 \mathrm{kcal} / \mathrm{mol}^{\mathrm{CHO}} \mathrm{CH}^{\mathrm{a}}$ is more stable than $\mathrm{CHO}^{\mathrm{b}}$ by $0.20 \mathrm{kcal} / \mathrm{mol}$.

We now turn to 7-R-1,2-benzo-3- $\mathrm{CO}_{2} \mathrm{Me}-\mathrm{cyclobutene}$ and explore the ring-opening features in the context of activation energies and NBO interaction, as above. The relevant data for the inward and outward opening transition structures are collected in Table 2. Like 6-R-1,2-benzo-3- $\mathrm{CO}_{2} \mathrm{Me}-$ cyclobutene, the outward opening is favored over the inward opening from the differential activation energies and the inward opening from the differential $\sigma_{\mathrm{cзc4}}-\pi^{*}$ co interactions. The relative acceptor strength form the consideration of the activation energies for outward opening is $\mathrm{COMe}<\mathrm{CHO}<\mathrm{CN}<$ 
$\mathrm{NO}<\mathrm{H}<\mathrm{NO}_{2}$ for the $a$ series of materials and $\mathrm{CN}<\mathrm{H}<\mathrm{NO}_{2}<\mathrm{COMe}<\mathrm{NO}<\mathrm{CHO}$ for the $b$ series materials. Other than being very different from each other, the order looks suspicious. How could $\mathrm{H}$ ever be a more powerful acceptor than even CN? The relative acceptor order from the NBO interactions in the inward opening transition structures is $\mathrm{H}<\mathrm{COMe}<\mathrm{CHO}<\mathrm{CN}<\mathrm{NO}<\mathrm{NO}_{2}$ for both the series of materials. This order is more sensible than the one based on the activation energy above. The $\mathrm{H}$ is the least powerful acceptor and $\mathrm{NO}_{2}$ the most powerful among the groups studied herein. The $\mathrm{CN}$ group here as well shows up to be a better acceptor than the COMe and $\mathrm{CHO}$ groups. The relative order of the acceptor strengths of the prominent groups $\mathrm{COMe}, \mathrm{CHO}$ and $\mathrm{NO}_{2}$ remains, however, unchanged from COMe $<\mathrm{CHO}<\mathrm{NO}_{2} .^{3}$

Conclusion: It has been shown that the performance of the NBO approach to the prediction of the torquoselectivity of the ring-opening of 1,2-benzo-3- $\mathrm{CO}_{2} \mathrm{Me}-\mathrm{cyclobutenes}$ bearing substituents on the aromatic ring and also the estimation of the relative resonance-acceptor strengths of the substituents is superior to that of the activation energy approach. The relative resonance-acceptor strength of the common functional groups $\mathrm{COMe}, \mathrm{CHO}$ and $\mathrm{NO}_{2}$ estimated from the $\mathrm{NBO}$ approach is $\mathrm{COMe}<\mathrm{CHO}<$ $\mathrm{NO}_{2}$, which has general acceptability. Two important points, however, must be noted: (a) the present study recognizes $\mathrm{CN}$ as a better acceptor than $\mathrm{COMe}$ and $\mathrm{CHO}$ requires attention and (b) the relative acceptor strength estimated from the NBO study of the substituted 1,2-benzo-3- $\mathrm{CO}_{2} \mathrm{Me}$-cyclobutenes

(COMe $<\mathrm{CHO}<\mathrm{CN}<\mathrm{NO}<\mathrm{NO}_{2}$ ) is different the one estimated previously ${ }^{2}$ from the study of the 1substituted-3- $\mathrm{CO}_{2} \mathrm{Me}$-cyclobutenes $\left(\mathrm{CN}<\mathrm{COMe}<\mathrm{CHO}<\mathrm{NO}_{2}<\mathrm{NO}\right)$.

\section{ASSOCIATED CONTENT}

\section{Supporting Information}

Cartesian coordinates of the optimized substrates, transition structures and Gibbs' free energies (PDF)

\section{Author Information}

\section{Corresponding Authors}

vijendra@iitk.ac.in 
arpitayadav@yahoo.co.in

\section{Notes}

The authors declare no competing financial interest.

\section{ACKNOWLEDGEMENTS}

VKY thanks the Council of Scientific \& Industrial Research and Department of Science \& Technology, Government of India, for funding. VKY also acknowledges the generous allocation of time on HPC2013 series of supercomputers by the Computer Center of IIT Kanpur.

\section{REFERENCES AND NOTES}

1. Substituent effects on rates and stereoselectivities of conrotatory electrocyclic reactions of cyclobutenes. A theoretical study, Niwayama, S.; Kallel, E. A.; Spellmeyer, D. C.; Sheu, C.; Houk, K. N. J. Org. Chem.1996, 61, 2813-2825.

2. On the relative resonance-acceptor abilities of $\mathrm{CN}, \mathrm{NO}, \mathrm{COMe}, \mathrm{CHO}$ and $\mathrm{NO}_{2}$ groups, Yadav, V. K.; Yadav, A. (2019): ChemRxiv. https://doi.org/10.26434/chemrxiv.8081945.v1

3. "Nitro is the most powerful of the common groups and thereafter the series follows the approximate order $\mathrm{NO}_{2}>\mathrm{COR}>\mathrm{SO}_{2} \mathrm{R}>\mathrm{CO}_{2} \mathrm{R}>\mathrm{CN}>\mathrm{C}_{6} \mathrm{H}_{5}$." See: W. Carruthers in Some Modern Methods of Organic synthesis, Cambridge University Press, $3^{\text {rd }}$ Ed, $\mathrm{p} 1$.

4. On the Conrotatory Ring Opening of 3-Carbomethoxycyclobutene vis-a-vis 3-Carbomethoxy-1,2Benzocyclobutene and the Predominant Inward Opening of 3-Dimethylaminocarbonyl-1,2-Benzocyclobutene, Yadav, V. K.; Prasad, D. L. V. K.; Yadav, A.; Rao, M. L. N. (2018): ChemRxiv. https://doi.org/10.26434/chemrxiv.7094003.v1

5. Gaussian 09, Revision B.01, Frisch, M. J.; Trucks, G. W.; Schlegel, H. B.; Scuseria, G. E.; Robb, M. A.; Cheeseman, J. R.; Scalmani, G.; Barone, V.; Mennucci, B.; Peterson, G. A.; Nakatsuji, H.; Caricato, M.; Li, X.; Hratchian, H. P.; Izmaylov, A. F.; Bloino, J.; Zheng, G.; Sonnenberg, J. L.; Hada, M.; Ehara, M.; Toyota, K.; Fukuda, R.; Hasegawa, J.; Ishida, M.; Nakajima,T.; Honda, Y.; Kitao, O.; Nakai, H.; Vreven, T.; Montgomery, Jr., J. A.; Peralta, J. E.; Ogliaro, F.; Bearpark, M.; Heyd, J. J.; Brothers, E.; Kudin,K. N.; Staroverov, V. N.; Keith, T.; Kobayashi, R.; Normand, J.; Raghavachari, K.; Rendell, A.; Burant, J. C.; Iyengar, S. S.; Tomasi, J.; Cossi, M.; Rega, N.; Millam, J. M.; Klene, M.; Knox, J. E.; Cross, J. B.; Bakken, V.; Adamo, C.; Jaramillo, J.; Gomperts, R.; 
Stratmann, R. E.; Yazyev, O.; Austin, A. J.; Cammi, R.; Pomelli, C.; Ochterski, J. W.; Martin, R. L.; Morokuma, K.; Zakrzewski, V. G.; Voth, G. A.; Salvador, P.; Dannenberg, J. J.; Dapprich, S.; Daniels, A. D.; Farkas, O.; Foresman, J. B.; Ortiz, J. V.; Cioslowski, J.; Fox, D. J. Gaussian, Inc., Wallingford CT, 2010. 
Supplementary Information

on

\title{
Activation energy and NBO interaction approaches to the determination of the relative resonance acceptor strengths of $\mathrm{CN}, \mathrm{NO}, \mathrm{COMe}, \mathrm{CHO}$ and $\mathrm{NO}_{2}$ groups from the ring-opening of 1,2-benzo-3-carbomethoxycyclobutenes
}

\author{
Veejendra K Yadav ${ }^{\mathrm{a}}$ and Arpita Yadav ${ }^{\mathrm{b}}$ \\ aDepartment of Chemistry, Indian Institute of Technology, Kanpur 208016, India \\ ${ }^{b}$ Department of Chemistry, University Institute of Engineering \& Technology, CSJM University, Kanpur 208024, India
}

Table of Contents

1. $\mathrm{MP} 2 / 6-31+\mathrm{G}(\mathrm{d}, \mathrm{p})$ coordinates of $4, \mathrm{R}=\mathrm{H}, \mathrm{CN}, \mathrm{NO}, \mathrm{COMe}, \mathrm{CHO}, \mathrm{NO}_{2}$ S2-S6

2. $M P 2 / 6-31+G(d, p)$ coordinates of the transition structures for the reactions $\mathbf{4 \rightarrow 6}$ and $\mathbf{4 \rightarrow 5}$ S6-S15

3. $\mathrm{MP} 2 / 6-31+\mathrm{G}(\mathrm{d}, \mathrm{p})$ coordinates of $7, \mathrm{R}=\mathrm{CN}, \mathrm{NO}, \mathrm{COMe}, \mathrm{CHO}, \mathrm{NO}_{2}$

4. $M P 2 / 6-31+G(d, p)$ coordinates of the transition structures for the reactions $\mathbf{7} \rightarrow \mathbf{9}$ and $\mathbf{7 \rightarrow \mathbf { 8 }}$ S19-S27 
4, $\mathrm{R}=\mathrm{H}(\mathrm{G}=-535.797806$ Hartrees $)$

\begin{tabular}{|c|c|c|c|c|c|}
\hline 1 & 6 & $\odot$ & -1.425556 & 0.937675 & 0.037653 \\
\hline 2 & 6 & $\odot$ & $-\odot .322398$ & 1.938248 & 0.349680 \\
\hline 3 & 6 & $\odot$ & $\odot .530787$ & $\odot .706851$ & 0.817871 \\
\hline 4 & 6 & $\odot$ & -0.665082 & -0.160689 & 0.443078 \\
\hline 5 & 1 & $\odot$ & -0.540779 & 2.655134 & 1.142824 \\
\hline 6 & 1 & $\odot$ & 0.108228 & 2.457798 & -0.506105 \\
\hline 7 & 1 & $\odot$ & $\odot .780880$ & 0.696470 & 1.882040 \\
\hline 8 & 6 & $\odot$ & 1.772526 & 0.424535 & ๑. 014859 \\
\hline 9 & 8 & $\odot$ & 2.266687 & 1.149046 & -0.837475 \\
\hline 10 & 6 & $\odot$ & -1.127339 & -1.470549 & ๑. 394471 \\
\hline 11 & 6 & $\odot$ & -2.727599 & ๑. 797824 & -0.431908 \\
\hline 12 & 1 & $\odot$ & -3.340110 & 1.634628 & -0.747328 \\
\hline 13 & 6 & $\odot$ & -2.438761 & -1.621845 & -0.087176 \\
\hline 14 & 6 & $\odot$ & -3.215679 & -0.519188 & -0.489813 \\
\hline 15 & 8 & $\odot$ & 2.277939 & -0.788417 & $\odot .357621$ \\
\hline 16 & 6 & $\odot$ & 3.459206 & -1.175746 & -0.379822 \\
\hline 17 & 1 & $\odot$ & 4.252866 & -0.448762 & -0.224774 \\
\hline 18 & 1 & $\odot$ & 3.230876 & -1.245155 & -1.440811 \\
\hline 19 & 1 & $\odot$ & 3.735070 & -2.144356 & $\odot .022219$ \\
\hline 20 & 1 & $\odot$ & -0.533340 & -2.322129 & $\odot .7 \odot 4127$ \\
\hline 21 & 1 & $\odot$ & -4.221508 & -0.697444 & -0.851886 \\
\hline 22 & 1 & $\odot$ & -2.869827 & -2.613918 & -0.154843 \\
\hline
\end{tabular}

4, $\mathrm{R}=\mathrm{CN}(\mathrm{G}=-627.813836$ Hartrees $)$

\begin{tabular}{|c|c|c|c|c|c|}
\hline 1 & 6 & $\odot$ & 0.673086 & 1.119421 & -0.177020 \\
\hline 2 & 6 & $\odot$ & -0.534961 & 2.032765 & -0.318630 \\
\hline 3 & 6 & $\odot$ & -1.321533 & $\odot .760055$ & -0.793406 \\
\hline 4 & 6 & $\odot$ & $-\odot .029007$ & $-\odot .017068$ & -0.587128 \\
\hline 5 & 1 & $\Theta$ & $-\odot .449196$ & 2.814966 & -1.073836 \\
\hline 6 & 1 & $\Theta$ & -0.921800 & 2.456027 & 0.607955 \\
\hline 7 & 1 & $\odot$ & -1.666455 & ๑.792311 & -1.830294 \\
\hline 8 & 6 & $\odot$ & -2.459266 & ๑. 322186 & ๑. 092996 \\
\hline 9 & 8 & $\odot$ & -2.962162 & $\odot .974514$ & ๑.996186 \\
\hline 10 & 6 & $\odot$ & $\odot .546399$ & -1.279076 & -0.678552 \\
\hline 11 & 6 & $\Theta$ & 2.020491 & 1.077872 & 0.153603 \\
\hline 12 & 1 & $\odot$ & 2.597867 & 1.939393 & ๑. 467294 \\
\hline 13 & 6 & $\odot$ & 1.904328 & -1.348593 & -0.337265 \\
\hline 14 & 1 & $\Theta$ & 2.429767 & -2.295014 & -0.379495 \\
\hline 15 & 6 & $\Theta$ & 2.620665 & -0.198051 & $\odot .066909$ \\
\hline 16 & 8 & $\Theta$ & -2.851204 & -0.930617 & -0.247435 \\
\hline 17 & 6 & $\odot$ & -3.934939 & -1.459469 & 0.552426 \\
\hline 18 & 1 & $\odot$ & -4.808295 & -0.817464 & 0.468256 \\
\hline 19 & 1 & $\odot$ & -3.630080 & -1.527568 & 1.593923 \\
\hline 20 & 1 & $\odot$ & -4.132732 & -2.442442 & ๑.139914 \\
\hline 21 & 1 & $\Theta$ & $-\odot .0 \odot \odot 223$ & -2.160174 & -0.991604 \\
\hline 22 & 6 & $\odot$ & 4.011315 & -0.338946 & ๑. 401569 \\
\hline 23 & 7 & $\Theta$ & 5.158371 & -0.448255 & 0.679266 \\
\hline
\end{tabular}


4, $\mathrm{R}=\mathrm{NO}^{\mathrm{a}}(\mathrm{G}=-664.786778$ Hartrees, torsion angle 5-6-N-0=๑.๑)

\begin{tabular}{|c|c|c|c|c|c|}
\hline 1 & 6 & $\odot$ & 0.684521 & 1.012222 & -0.249258 \\
\hline 2 & 6 & $\odot$ & -0.475771 & 1.980096 & -0.429344 \\
\hline 3 & 6 & $\odot$ & -1.332965 & 0.731263 & -0.837296 \\
\hline 4 & 6 & $\odot$ & -0.083833 & -0.106408 & -0.602339 \\
\hline 5 & 1 & $\odot$ & -0.354372 & 2.719244 & -1.222047 \\
\hline 6 & 1 & $\odot$ & -0.831450 & 2.467771 & 0.477842 \\
\hline 7 & 1 & $\odot$ & -1.685635 & 0.731155 & -1.872073 \\
\hline 8 & 6 & $\odot$ & -2.483942 & $\odot .396836$ & $\odot .077031$ \\
\hline 9 & 8 & $\odot$ & -2.936897 & 1.113406 & $\odot .957569$ \\
\hline 10 & 6 & $\odot$ & 0.413649 & -1.404043 & -0.630444 \\
\hline 11 & 6 & $\odot$ & $2.0259 \odot 9$ & $\odot .918278$ & $\odot .083787$ \\
\hline 12 & 1 & $\odot$ & 2.661039 & $1.75200 \odot$ & $\odot .356221$ \\
\hline 13 & 6 & $\odot$ & 1.768063 & -1.523997 & -0.286717 \\
\hline 14 & 1 & $\odot$ & 2.263754 & -2.487790 & -0.274780 \\
\hline 15 & 6 & $\odot$ & 2.538032 & -0.395635 & 0.058592 \\
\hline 16 & 8 & $\odot$ & -2.952044 & -0.843623 & -0.207832 \\
\hline 17 & 6 & $\odot$ & -4.053713 & -1.275998 & $\odot .624922$ \\
\hline 18 & 1 & $\odot$ & -4.889988 & -0.588712 & $\odot .523508$ \\
\hline 19 & 1 & $\Theta$ & -3.739605 & -1.318887 & 1.664997 \\
\hline 20 & 1 & $\odot$ & -4.312682 & -2.261958 & $\odot .255707$ \\
\hline 21 & 7 & $\odot$ & 3.905796 & -0.717261 & $\odot .376117$ \\
\hline 22 & 8 & $\odot$ & 4.605757 & 0.264910 & $\odot .688091$ \\
\hline 23 & 1 & $\odot$ & -0.185869 & -2.265214 & -0.898430 \\
\hline
\end{tabular}

4, $\mathrm{R}=\mathrm{NO}^{\mathrm{b}}(\mathrm{G}=-664.786300$ Hartrees, torsion angle $5-6-\mathrm{N}-0=180 . \odot)$

\begin{tabular}{|c|c|c|c|c|c|}
\hline 1 & 6 & $\odot$ & $-\odot .567633$ & 1.235008 & 0.134961 \\
\hline 2 & 6 & $\odot$ & $\odot .686964$ & 2.084186 & $\odot .272744$ \\
\hline 3 & 6 & $\odot$ & 1.396559 & $\odot .781198$ & $\odot .784063$ \\
\hline 4 & 6 & $\odot$ & ๑. 065012 & 0.071803 & 0.581254 \\
\hline 5 & 1 & $\odot$ & $\odot .635937$ & 2.885402 & 1.010948 \\
\hline 6 & 1 & $\odot$ & 1.106929 & 2.465853 & -0.657403 \\
\hline 7 & 1 & $\odot$ & 1.734032 & 0.816853 & 1.823339 \\
\hline 8 & 6 & $\odot$ & 2.514317 & $\odot .258119$ & -0.081446 \\
\hline 9 & 8 & $\odot$ & 3.056574 & 0.856278 & -0.999160 \\
\hline 10 & 6 & $\odot$ & -0.574318 & -1.162801 & 0.688133 \\
\hline 11 & 6 & $\odot$ & -1.910739 & 1.246681 & -0.219063 \\
\hline 12 & 1 & $\odot$ & -2.459376 & 2.115014 & $-\odot .565492$ \\
\hline 13 & 6 & $\odot$ & -1.925878 & -1.174863 & 0.327786 \\
\hline 14 & 1 & $\odot$ & -2.511639 & -2.084286 & $\odot .376761$ \\
\hline 15 & 6 & $\odot$ & -2.563717 & ๑. . 004399 & -0.113718 \\
\hline 16 & 8 & $\odot$ & 2.835730 & -1.004114 & $\odot .296425$ \\
\hline 17 & 6 & $\odot$ & 3.892472 & -1.613678 & -0.481937 \\
\hline 18 & 1 & $\odot$ & 4.799995 & -1.019509 & -0.408557 \\
\hline 19 & 1 & $\odot$ & 3.589813 & -1.692076 & -1.523329 \\
\hline 20 & 1 & $\odot$ & 4.032541 & -2.594891 & -0.042471 \\
\hline 21 & 7 & $\odot$ & -3.954720 & 0.046808 & -0.493025 \\
\hline 22 & 8 & $\odot$ & -4.548828 & -1.044773 & -0.415847 \\
\hline 23 & 1 & $\odot$ & -0.071232 & $-2.05946 \odot$ & 1.029374 \\
\hline
\end{tabular}

4, $\mathrm{R}=\mathrm{COMe}^{\mathrm{a}}(\mathrm{G}=-687.994469$ Hartrees, torsion angle $5-6-\mathrm{C}-0=0 . \odot)$ 


\begin{tabular}{|c|c|c|c|c|c|}
\hline 1 & 6 & 0 & ๑. 205011 & 1.188752 & $-\odot .242481$ \\
\hline 2 & 6 & $\odot$ & -1.040005 & 2.057600 & $-\odot .349805$ \\
\hline 3 & 6 & $\odot$ & -1.794016 & $\odot .757356$ & $-\odot .80200 \odot$ \\
\hline 4 & 6 & $\odot$ & -0.468029 & ๑. 027554 & $-\odot .633874$ \\
\hline 5 & 1 & 0 & -1.006397 & 2.841735 & -1.107346 \\
\hline 6 & 1 & 0 & -1.415378 & 2.467597 & ๑.587453 \\
\hline 7 & 1 & 0 & -2.172137 & 0.775566 & -1.827622 \\
\hline 8 & 6 & 0 & -2.884753 & $\odot .275209$ & ๑.118498 \\
\hline 9 & 8 & 0 & -3.367194 & ๑.894278 & 1.055785 \\
\hline 10 & 6 & 0 & 0.150511 & -1.212472 & -0.726514 \\
\hline 11 & 6 & 0 & 1.557422 & 1.192712 & ๑.062351 \\
\hline 12 & 1 & 0 & 2.117530 & 2.070005 & 0.362029 \\
\hline 13 & 6 & $\odot$ & 1.519111 & -1.224543 & -0.413093 \\
\hline 14 & 1 & $\odot$ & 2.054647 & -2.163798 & $-\odot .468428$ \\
\hline 15 & 6 & $\odot$ & 2.212263 & $-\odot .055781$ & -0.023228 \\
\hline 16 & 8 & 0 & -3.260725 & $-\odot .981356$ & -0.231219 \\
\hline 17 & 6 & 0 & -4.293773 & -1.552531 & 0.604410 \\
\hline 18 & 1 & 0 & -5.187630 & -0.934457 & 0.568956 \\
\hline 19 & 1 & 0 & -3.943320 & -1.628611 & 1.630987 \\
\hline 20 & 1 & $\odot$ & -4.482551 & -2.534134 & 0.184173 \\
\hline 21 & 1 & $\odot$ & -0.368798 & -2.115660 & -1.023809 \\
\hline 22 & 6 & $\odot$ & 4.396520 & -1.425511 & ๑. 299699 \\
\hline 23 & 1 & 0 & 3.935220 & -2.113686 & 1.008891 \\
\hline 24 & 1 & 0 & 5.432064 & -1.251942 & 0.579514 \\
\hline 25 & 1 & $\odot$ & 4.359964 & -1.886975 & $-\odot .687935$ \\
\hline 26 & 6 & 0 & 3. 675322 & $-\odot .095407$ & ๑. 295583 \\
\hline 27 & 8 & $\odot$ & 4.285830 & 0.946668 & 0.557415 \\
\hline
\end{tabular}

4, $\mathrm{R}=\mathrm{COMe}^{\mathrm{b}}(\mathrm{G}=-687.995085$ Hartrees, torsion angle 5-6-C-0=180.๑0)

\begin{tabular}{|c|c|c|c|c|c|}
\hline 1 & 6 & $\odot$ & $\odot .240679$ & 1.114286 & -0.307669 \\
\hline 2 & 6 & $\odot$ & -0.970848 & 2.023612 & -0.455889 \\
\hline 3 & 6 & $\odot$ & -1.773977 & 0.730860 & -0.838892 \\
\hline 4 & 6 & $\odot$ & -0.473668 & -0.037295 & -0.641256 \\
\hline 5 & 1 & $\odot$ & -0.911663 & 2.764541 & -1.254470 \\
\hline 6 & 1 & $\odot$ & -1.328077 & 2.495885 & 0.458947 \\
\hline 7 & 1 & $\odot$ & -2.159753 & 0.711614 & -1.861588 \\
\hline 8 & 6 & $\odot$ & -2.872387 & 0.335240 & 0.113446 \\
\hline 9 & 8 & $\odot$ & -3.314087 & 1.013312 & 1.030138 \\
\hline 10 & 6 & $\odot$ & 0.102340 & -1.303164 & -0.684958 \\
\hline 11 & 6 & $\odot$ & 1.597123 & 1.082282 & $-\odot .0 \odot 8164$ \\
\hline 12 & 1 & $\odot$ & 2.157894 & 1.973072 & 0.246873 \\
\hline 13 & 6 & $\odot$ & 1.467744 & -1.350140 & -0.377571 \\
\hline 14 & 1 & $\odot$ & 2.002148 & -2.292089 & -0.386189 \\
\hline 15 & 6 & $\odot$ & 2.206375 & $-\odot .191264$ & -0.044802 \\
\hline 16 & 8 & $\odot$ & -3.305391 & -0.916822 & -0.178203 \\
\hline 17 & 6 & $\odot$ & -4.346085 & -1.411539 & ๑. 695935 \\
\hline 18 & 1 & $\odot$ & -5.215004 & -0.759625 & $\odot .648902$ \\
\hline 19 & 1 & $\odot$ & -3.981059 & -1.460366 & 1.719059 \\
\hline 20 & 1 & $\odot$ & -4.580681 & -2.400831 & $\odot .319194$ \\
\hline 21 & 1 & $\odot$ & -0.451616 & -2.199083 & $-\odot .938556$ \\
\hline 22 & 6 & $\odot$ & 4.472986 & 0.844678 & 0.668563 \\
\hline 23 & 1 & $\odot$ & 4.471016 & 1.590907 & $-\odot .126986$ \\
\hline
\end{tabular}




$\begin{array}{rrrrrr}24 & 1 & 0 & 5.493137 & 0.525347 & \odot .863778 \\ 25 & 1 & 0 & 4.057037 & 1.308094 & 1.564026 \\ 26 & 6 & 0 & 3.661325 & -0.367286 & 0.267205 \\ 27 & 8 & 0 & 4.191601 & -1.481377 & 0.201980\end{array}$

4, $\mathrm{R}=\mathrm{CHO}^{\mathrm{a}}(\mathrm{G}=-648.828009$ Hartrees, torsion angle 5-6-C-0=๑. 0 )

\begin{tabular}{|c|c|c|c|c|c|}
\hline 1 & 6 & $\odot$ & 0.658495 & 1.014961 & $-\odot .248779$ \\
\hline 2 & 6 & $\odot$ & -0.505075 & 1.979058 & -0.428202 \\
\hline 3 & 6 & $\odot$ & -1.359602 & 0.725912 & -0.830897 \\
\hline 4 & 6 & $\odot$ & -0.106711 & -0.105877 & -0.591826 \\
\hline 5 & 1 & $\odot$ & $-\odot .388322$ & 2.716441 & -1.223398 \\
\hline 6 & 1 & $\odot$ & -0.861212 & 2.468647 & ๑.477811 \\
\hline 7 & 1 & $\odot$ & -1.709867 & 0.720594 & -1.866515 \\
\hline 8 & 6 & $\odot$ & -2.511675 & 0.392641 & $\odot . \odot 81359$ \\
\hline 9 & 8 & $\odot$ & -2.969381 & 1.109943 & $\odot .959119$ \\
\hline 10 & 6 & $\odot$ & 0.400121 & -1.399203 & -0.628324 \\
\hline 11 & 6 & $\odot$ & $2.0 \odot 5698$ & 0.921412 & $\odot .06456 \odot$ \\
\hline 12 & 1 & $\odot$ & 2.640749 & 1.759987 & $\odot .325373$ \\
\hline 13 & 6 & $\odot$ & 1.758796 & -1.510937 & -0.294976 \\
\hline 14 & 1 & $\odot$ & 2.234075 & -2.486994 & -0.294292 \\
\hline 15 & 6 & $\odot$ & 2.540944 & -0.383987 & $\odot .035718$ \\
\hline 16 & 8 & $\odot$ & -2.977339 & -0.850484 & -0.200239 \\
\hline 17 & 6 & $\odot$ & -4.079355 & -1.281467 & $\odot .631875$ \\
\hline 18 & 1 & $\odot$ & -4.916869 & -0.596110 & $\odot .527051$ \\
\hline 19 & 1 & $\odot$ & -3.767461 & -1.320408 & 1.672847 \\
\hline 20 & 1 & $\odot$ & -4.336405 & -2.269207 & $\odot .265844$ \\
\hline 21 & 1 & $\odot$ & -0.196447 & -2.264695 & - ๑. 889852 \\
\hline 22 & 6 & $\odot$ & 3.963764 & -0.601629 & $\odot .379951$ \\
\hline 23 & 8 & $\odot$ & 4.747311 & 0. 292882 & $\odot .69664 \odot$ \\
\hline 24 & 1 & $\odot$ & 4.304630 & -1.652271 & $\odot .338216$ \\
\hline
\end{tabular}

4, $\mathrm{R}=\mathrm{CHO}^{\mathrm{b}}(\mathrm{G}=-648.827913$ Hartrees, torsion angle $5-6-\mathrm{C}-0=180.0)$

\begin{tabular}{|c|c|c|c|c|c|}
\hline 1 & 6 & $\odot$ & $\odot .544636$ & 1.227422 & -0.140756 \\
\hline 2 & 6 & $\odot$ & $-\odot .709798$ & 2.076433 & -0.282378 \\
\hline 3 & 6 & $\odot$ & -1.420738 & $\odot .770080$ & -0.783115 \\
\hline 4 & 6 & $\odot$ & $-\odot .088683$ & ๑. 061450 & -0.576713 \\
\hline 5 & 1 & $\odot$ & -0.659812 & 2.871452 & -1.027618 \\
\hline 6 & 1 & $\odot$ & -1.129839 & 2.466148 & ๑.644501 \\
\hline 7 & 1 & $\odot$ & -1.759401 & ๑.798118 & -1.822179 \\
\hline 8 & 6 & $\odot$ & -2.537077 & ๑.254909 & ๑. 088175 \\
\hline 9 & 8 & $\Theta$ & -3.065311 & ๑.852736 & 1.014718 \\
\hline 10 & 6 & $\odot$ & 0.556317 & -1.168072 & -0.688374 \\
\hline 11 & 6 & $\odot$ & 1.892206 & 1.244837 & $\odot .197045$ \\
\hline 12 & 1 & 0 & 2.418038 & 2.134392 & 0.530225 \\
\hline 13 & 6 & 0 & 1.911283 & -1.167765 & -0.336099 \\
\hline 14 & 1 & 0 & 2.499118 & -2.076727 & -0.386615 \\
\hline 15 & 6 & 0 & 2.563683 & ๑.0०9822 & ๑.091953 \\
\hline 16 & 8 & 0 & -2.875563 & -1.002030 & -0.293235 \\
\hline 17 & 6 & 0 & -3.928758 & -1.605639 & ๑.493731 \\
\hline 18 & 1 & 0 & -4.830868 & -1.001489 & ๑.436137 \\
\hline 19 & 1 & 0 & -3.614298 & -1.694937 & 1.530800 \\
\hline 20 & 1 & $\odot$ & $-4 . \odot 849 \odot 9$ & -2.582239 & $\odot .049352$ \\
\hline
\end{tabular}




$\begin{array}{rrrrrr}21 & 1 & \odot & 0.056955 & -2.069488 & -1.022606 \\ 22 & 6 & \odot & 3.996856 & -0.046786 & 0.459284 \\ 23 & 8 & \odot & 4.689615 & -1.063116 & 0.421789 \\ 24 & 1 & \odot & 4.435527 & 0.913903 & 0.785307\end{array}$

4, $\mathrm{R}=\mathrm{NO}_{2}(\mathrm{G}=-739.816649$ Hartrees $)$

\begin{tabular}{|c|c|c|c|c|c|}
\hline 1 & 6 & $\odot$ & $\odot .273609$ & 1.162216 & $-\odot .200652$ \\
\hline 2 & 6 & $\odot$ & -0.949552 & 2. 061952 & -0.285673 \\
\hline 3 & 6 & $\odot$ & -1.729251 & $\odot .794118$ & -0.783192 \\
\hline 4 & 6 & $\odot$ & -0.421988 & 0.029397 & -0.631491 \\
\hline 5 & 1 & $\odot$ & -0.890966 & 2.869419 & -1.016342 \\
\hline 6 & 1 & $\odot$ & -1.319321 & 2.448957 & 0.663397 \\
\hline 7 & 1 & $\odot$ & -2.100280 & 0.854326 & -1.809642 \\
\hline 8 & 6 & $\odot$ & -2.837968 & ๑. 310597 & 0.116652 \\
\hline 9 & 8 & $\odot$ & -3.323217 & ๑. 923779 & 1.056146 \\
\hline 10 & 6 & $\odot$ & $\odot .167882$ & -1.222860 & -0.759970 \\
\hline 11 & 6 & $\odot$ & 1.626886 & 1.134093 & $\odot .110964$ \\
\hline 12 & 1 & $\odot$ & 2.209549 & 1.985500 & 0.435282 \\
\hline 13 & 6 & $\odot$ & 1.531693 & -1.287026 & -0.438781 \\
\hline 14 & 1 & $\odot$ & 2.079221 & -2.217228 & -0.501269 \\
\hline 15 & 6 & $\odot$ & 2.211902 & -0.133608 & -0.018739 \\
\hline 16 & 8 & $\odot$ & -3.224699 & -0.933604 & -0.259034 \\
\hline 17 & 6 & $\odot$ & -4.280119 & -1.504840 & $\odot .549912$ \\
\hline 18 & 1 & $\odot$ & -5.163118 & -0.871745 & 0.511741 \\
\hline 19 & 1 & $\odot$ & -3.946361 & -1.605674 & 1.579789 \\
\hline 20 & 1 & $\odot$ & -4.476838 & -2.475038 & 0.107767 \\
\hline 21 & 7 & $\odot$ & 3.644234 & -0.264706 & ๑. 295584 \\
\hline 22 & 8 & $\odot$ & 4.320256 & $\odot .780541$ & $\odot .33565 \odot$ \\
\hline 23 & 8 & $\odot$ & 4.091393 & -1.407870 & 0.504373 \\
\hline 24 & 1 & $\odot$ & -0.369954 & -2.102577 & -1.091072 \\
\hline
\end{tabular}

TS for 4 $\rightarrow \mathbf{6}, \mathrm{R}=\mathrm{H}(\mathrm{G}=-535.737807$ Hartrees $)$

$\begin{array}{rrrrrr}1 & 6 & 0 & -1.032551 & 0.809732 & 0.414758 \\ 2 & 6 & 0 & -0.018747 & 1.428833 & 1.201033 \\ 3 & 6 & 0 & 0.568138 & -0.783755 & 0.759996 \\ 4 & 6 & 0 & -0.822517 & -0.593204 & 0.489417 \\ 5 & 1 & 0 & 0.132167 & 1.062813 & 2.206841 \\ 6 & 1 & 0 & 0.367596 & 2.422984 & 0.983954 \\ 7 & 1 & 0 & 0.936231 & -1.597377 & 1.383373 \\ 8 & 6 & 0 & 1.579571 & -0.220343 & -0.166193 \\ 9 & 8 & 0 & 1.386032 & 0.264526 & -1.274927 \\ 10 & 6 & 0 & -1.867020 & -1.494360 & 0.221581 \\ 11 & 6 & 0 & -2.134705 & 1.329113 & -0.292777 \\ 12 & 1 & 0 & -2.258445 & 2.393062 & -0.459375 \\ 13 & 6 & 0 & -3.011835 & -0.963600 & -0.368319 \\ 14 & 6 & 0 & -3.126974 & 0.421224 & -0.648920 \\ 15 & 8 & 0 & 2.828207 & -0.409654 & 0.359531 \\ 16 & 6 & 0 & 3.900535 & 0.041472 & -0.493029 \\ 17 & 1 & 0 & 3.820191 & 1.112784 & -0.665760 \\ 18 & 1 & 0 & 3.871813 & -0.480759 & -1.446725 \\ 19 & 1 & 0 & 4.808895 & -0.194256 & 0.051319\end{array}$




$\begin{array}{rrrrrr}20 & 1 & \odot & -1.750200 & -2.563836 & 0.357643 \\ 21 & 1 & 0 & -4.022923 & 0.779404 & -1.142275 \\ 22 & 1 & \odot & -3.822616 & -1.624470 & -0.651114\end{array}$

TS for 4 $\rightarrow \mathbf{5}, \mathrm{R}=\mathrm{H}(\mathrm{G}=-535.741067$ Hartrees $)$

\begin{tabular}{|c|c|c|c|c|c|}
\hline 1 & 6 & $\odot$ & 1.569238 & 1.010525 & ๑. 081588 \\
\hline 2 & 6 & 0 & $\odot .734839$ & 2.109064 & $\odot .455630$ \\
\hline 3 & 6 & $\odot$ & -0.577058 & 0.448896 & -0.417505 \\
\hline 4 & 6 & $\odot$ & $\odot .711885$ & -0.104331 & -0.104181 \\
\hline 5 & 1 & $\odot$ & $\odot .973678$ & 3.143093 & 0.212305 \\
\hline 6 & 1 & $\odot$ & ๑.062225 & 1.962636 & 1.289620 \\
\hline 7 & 1 & 0 & $-\odot .644757$ & 1.142757 & -1.244722 \\
\hline 8 & 6 & 0 & -1.830438 & $-\odot .192860$ & 0.012371 \\
\hline 9 & 8 & 0 & -1.901779 & -1.195254 & ๑.719784 \\
\hline 10 & 6 & $\odot$ & 1.208853 & -1.417170 & -0.051642 \\
\hline 11 & 6 & 0 & 2.963193 & 0.872225 & -0.065529 \\
\hline 12 & 1 & 0 & 3. 631884 & 1.724885 & -0.027962 \\
\hline 13 & 6 & 0 & 2.596144 & -1.555411 & -0.073828 \\
\hline 14 & 6 & $\odot$ & 3.455133 & -0.430410 & -0.111643 \\
\hline 15 & 8 & $\odot$ & -2.916916 & 0.471429 & -0.465234 \\
\hline 16 & 6 & $\odot$ & -4.183417 & -0.092918 & -0.061178 \\
\hline 17 & 1 & $\odot$ & -4.261152 & -0.102181 & 1.023749 \\
\hline 18 & 1 & $\odot$ & -4.279905 & -1.107788 & -0.440171 \\
\hline 19 & 1 & $\odot$ & -4.932073 & $\odot .557919$ & -0.499334 \\
\hline 20 & 1 & $\odot$ & $\odot .551493$ & -2.276801 & -0.083184 \\
\hline 21 & 1 & $\odot$ & 4.525573 & $-\odot .592333$ & -0.162970 \\
\hline 22 & 1 & $\odot$ & 3.032363 & -2.547250 & $-\odot . \odot 88229$ \\
\hline
\end{tabular}

TS for $\mathbf{4} \rightarrow \mathbf{6}, \mathrm{R}=\mathrm{CN}(\mathrm{G}=-627.752286$ Hartrees $)$

\begin{tabular}{|c|c|c|c|c|c|}
\hline 1 & 6 & $\odot$ & $\odot .401798$ & $-\odot .321849$ & $\odot .866062$ \\
\hline 2 & 6 & $\odot$ & $-\odot .639991$ & -0.735183 & 1.742242 \\
\hline 3 & 6 & 0 & -1.367851 & 1.051830 & ๑. 415501 \\
\hline 4 & 6 & $\odot$ & 0.055578 & 0.965726 & 0.373930 \\
\hline 5 & 1 & $\odot$ & -0.959559 & -0.037116 & 2.503229 \\
\hline 6 & 1 & $\odot$ & -0.897795 & -1.780456 & 1.897962 \\
\hline 7 & 1 & $\odot$ & -1.892206 & 1.981615 & 0.630547 \\
\hline 8 & 6 & $\odot$ & -2.184546 & ๑.035631 & -0.299772 \\
\hline 9 & 8 & 0 & -1.786581 & -0.792783 & -1.109171 \\
\hline 10 & 6 & $\odot$ & 1.041182 & 1.839185 & -0.117966 \\
\hline 11 & 6 & $\odot$ & 1.622925 & $-\odot .919127$ & 0.504713 \\
\hline 12 & 1 & 0 & 1.873040 & -1.941856 & 0.761696 \\
\hline 13 & 6 & $\odot$ & 2.296506 & 1.295649 & -0.363429 \\
\hline 14 & 1 & $\odot$ & 3.078910 & 1.900559 & -0.804765 \\
\hline 15 & 6 & $\odot$ & 2.566454 & -0.075487 & -0.086625 \\
\hline 16 & 8 & $\odot$ & -3.500908 & 0.224213 & 0.001775 \\
\hline 17 & 6 & $\odot$ & -4.400602 & -0.663119 & -0.697928 \\
\hline 18 & 1 & $\odot$ & -4.187876 & -1.697125 & -0.435334 \\
\hline 19 & 1 & $\odot$ & -4.297790 & -0.533350 & -1.772701 \\
\hline 20 & 1 & $\odot$ & -5.391589 & -0.375277 & -0.364145 \\
\hline 21 & 1 & $\odot$ & 0.813847 & 2.859999 & -0.403684 \\
\hline 22 & 6 & $\odot$ & 3.868863 & -0.592815 & $-\odot .407238$ \\
\hline 23 & 7 & $\odot$ & 4.942719 & -1.015868 & -0.675796 \\
\hline
\end{tabular}


TS for $\mathbf{4} \rightarrow \mathbf{5}, \mathrm{R}=\mathrm{CN}(\mathrm{G}=-627.755980$ Hartrees )

\begin{tabular}{|c|c|c|c|c|c|}
\hline 1 & 6 & $\odot$ & 0.816825 & 1.163297 & 0.116079 \\
\hline 2 & 6 & $\odot$ & $-\odot .081550$ & 2.215564 & 0.467277 \\
\hline 3 & 6 & $\odot$ & -1.282168 & $\odot .466124$ & -0.414817 \\
\hline 4 & 6 & $\odot$ & 0.029218 & -0.002106 & -0.071341 \\
\hline 5 & 1 & $\odot$ & $\odot .101703$ & 3.259076 & ๑. 219527 \\
\hline 6 & 1 & $\odot$ & -0.761800 & 2.031644 & 1.287577 \\
\hline 7 & 1 & $\odot$ & -1.374672 & 1.156609 & -1.242708 \\
\hline 8 & 6 & $\odot$ & -2.502071 & -0.253614 & -0.002658 \\
\hline 9 & 8 & $\odot$ & -2.512164 & -1.263324 & $\odot .696909$ \\
\hline 10 & 6 & $\odot$ & 0.597805 & -1.284297 & 0.018531 \\
\hline 11 & 6 & $\odot$ & 2.215504 & 1.108823 & -0.017488 \\
\hline 12 & 1 & $\odot$ & 2.842691 & 1.992401 & 0.011747 \\
\hline 13 & 6 & $\odot$ & 1.987447 & -1.351988 & 0.014093 \\
\hline 14 & 1 & $\odot$ & 2.487420 & -2.312717 & 0.021091 \\
\hline 15 & 6 & $\odot$ & 2.779520 & -0.171368 & -0.037357 \\
\hline 16 & 8 & $\odot$ & -3.617080 & ๑. 343782 & -0.491189 \\
\hline 17 & 6 & $\odot$ & -4.854570 & -0.301427 & -0.112067 \\
\hline 18 & 1 & $\odot$ & -4.947014 & -0.324660 & $\odot .971266$ \\
\hline 19 & 1 & $\odot$ & -4.880849 & -1.316155 & -0.501990 \\
\hline 20 & 1 & $\odot$ & -5.633724 & $\odot .307011$ & -0.557209 \\
\hline 21 & 1 & $\odot$ & $-\odot .0 \odot 8830$ & -2.180471 & $-\odot .0 \odot \odot 945$ \\
\hline 22 & 6 & $\odot$ & 4.209569 & -0.307423 & -0.095525 \\
\hline 23 & 7 & $\odot$ & 5.387978 & -0.420845 & -0.148925 \\
\hline
\end{tabular}

TS for $4 \rightarrow \mathbf{6}, \mathrm{R}=\mathrm{NO}^{\mathrm{a}}(\mathrm{G}=-664.724785$ Hartrees $)$

\begin{tabular}{|c|c|c|c|c|c|}
\hline 1 & 6 & $\odot$ & $\odot .402188$ & -0.279401 & ๑. 809197 \\
\hline 2 & 6 & 0 & -0.603437 & -0.753962 & 1.697213 \\
\hline 3 & 6 & 0 & -1.417653 & 1.058493 & ๑. 441986 \\
\hline 4 & 6 & $\odot$ & ๑. . 004852 & 1. 017172 & $\odot .370458$ \\
\hline 5 & 1 & 0 & $-\odot .926385$ & $-\odot .091008$ & 2.487727 \\
\hline 6 & 1 & 0 & -0.823384 & -1.811690 & 1.824175 \\
\hline 7 & 1 & $\odot$ & -1.964650 & 1.965650 & 0.693592 \\
\hline 8 & 6 & $\odot$ & -2.220591 & 0.034885 & $-\odot .278367$ \\
\hline 9 & 8 & 0 & -1.820192 & $-\odot .751884$ & -1.127058 \\
\hline 10 & 6 & 0 & 0.952865 & 1.945436 & $-\odot .097819$ \\
\hline 11 & 6 & 0 & 1.632007 & $-\odot .825620$ & 0.408280 \\
\hline 12 & 1 & 0 & 1.933355 & -1.845287 & 0.617258 \\
\hline 13 & 6 & 0 & 2.217953 & 1.446056 & -0.383451 \\
\hline 14 & 1 & $\odot$ & 2.987800 & 2.073314 & -0.816803 \\
\hline 15 & 6 & $\odot$ & 2.526898 & ๑.080141 & -0.159229 \\
\hline 16 & 8 & 0 & -3.532687 & $\odot .165902$ & ๑. 069959 \\
\hline 17 & 6 & $\odot$ & -4.422314 & -0.730294 & -0.631203 \\
\hline 18 & 1 & 0 & -4.166555 & -1.763888 & -0.408289 \\
\hline 19 & 1 & $\odot$ & -4.356862 & -0.563814 & -1.703860 \\
\hline 20 & 1 & $\odot$ & -5.411973 & $-\odot .487985$ & -0.259427 \\
\hline 21 & 7 & 0 & 3.868836 & $-\odot .281474$ & -0.564293 \\
\hline 22 & 8 & 0 & 4.168533 & -1.467821 & -0.343975 \\
\hline 23 & 1 & 0 & 0.684965 & 2.968008 & -0.338112 \\
\hline
\end{tabular}

TS for $\mathbf{4} \rightarrow \mathbf{5}, \mathrm{R}=\mathrm{NO}^{\mathrm{a}}(\mathrm{G}=-664.728586$ Hartrees $)$ 


\begin{tabular}{|c|c|c|c|c|c|}
\hline 1 & 6 & $\odot$ & ๑. 818117 & 1.060459 & 0.124476 \\
\hline 2 & 6 & $\odot$ & -0.025507 & 2.149736 & ๑. 499201 \\
\hline 3 & 6 & $\odot$ & -1.315309 & $\odot .463900$ & -0.403337 \\
\hline 4 & 6 & $\odot$ & -0.028326 & -0.067722 & -0.067769 \\
\hline 5 & 1 & $\odot$ & ๑. 206972 & 3.186484 & ๑.264855 \\
\hline 6 & 1 & $\odot$ & -0.709027 & 1.986378 & 1.321237 \\
\hline 7 & 1 & $\odot$ & -1.374465 & 1.177399 & -1.214671 \\
\hline 8 & 6 & $\odot$ & -2.569338 & -0.203590 & -0.005685 \\
\hline 9 & 8 & $\odot$ & -2.630806 & -1.224709 & 0.673984 \\
\hline 10 & 6 & $\odot$ & 0.474274 & -1.378562 & 0.018673 \\
\hline 11 & 6 & $\odot$ & 2.209825 & 0.944591 & -0.014350 \\
\hline 12 & 1 & $\odot$ & 2.890523 & 1.787174 & ๑. 018910 \\
\hline 13 & 6 & $\odot$ & 1.859820 & -1.505815 & 0.008238 \\
\hline 14 & 1 & $\odot$ & 2.335155 & -2.479533 & $\odot .005503$ \\
\hline 15 & 6 & $\odot$ & 2.696432 & -0.363873 & -0.039886 \\
\hline 16 & 8 & $\odot$ & -3.652752 & ๑. 457837 & -0.483360 \\
\hline 17 & 6 & $\odot$ & -4.921184 & -0.132322 & -0.117247 \\
\hline 18 & 1 & $\odot$ & -5.016283 & -0.171690 & 0.965397 \\
\hline 19 & 1 & $\odot$ & -4.997335 & -1.136858 & -0.526567 \\
\hline 20 & 1 & $\odot$ & -5.668564 & 0.522480 & -0.550936 \\
\hline 21 & 7 & $\odot$ & 4.106111 & -0.682132 & -0.102991 \\
\hline 22 & 8 & $\odot$ & 4.855469 & ๑.309898 & -0.137349 \\
\hline 23 & 1 & $\odot$ & -0.177864 & -2.241933 & -0.002877 \\
\hline
\end{tabular}

TS for $4 \rightarrow \mathbf{6}, \mathrm{R}=\mathrm{NO} \mathrm{O}^{\mathrm{b}} \quad(\mathrm{G}=-664.725565$ Hartrees $)$

\begin{tabular}{|c|c|c|c|c|c|}
\hline 1 & 6 & $\odot$ & 0.305893 & -0.549090 & 0.803924 \\
\hline 2 & 6 & 0 & $-\odot .771130$ & -1.043233 & 1.593793 \\
\hline 3 & 6 & $\odot$ & -1.383613 & 0.966629 & 0.590987 \\
\hline 4 & 6 & $\odot$ & ๑. 034022 & $\odot .818503$ & 0.533727 \\
\hline 5 & 1 & 0 & -1.052501 & -0.473358 & 2.468273 \\
\hline 6 & 1 & 0 & -1.096329 & -2.080965 & 1.562247 \\
\hline 7 & 1 & $\odot$ & -1.863092 & 1.872491 & ๑. 958884 \\
\hline 8 & 6 & $\odot$ & -2.246129 & 0.130830 & -0.286968 \\
\hline 9 & 8 & $\odot$ & -1.885462 & -0.572374 & -1.222188 \\
\hline 10 & 6 & 0 & 1.069682 & 1.715801 & ๑.199994 \\
\hline 11 & 6 & $\odot$ & 1.503775 & -1.132614 & 0.353440 \\
\hline 12 & 1 & $\odot$ & 1.724550 & -2.192001 & 0.422738 \\
\hline 13 & 6 & $\odot$ & 2.300054 & 1.163847 & -0.125696 \\
\hline 14 & 1 & $\odot$ & 3.124337 & 1.782186 & -0.456763 \\
\hline 15 & 6 & $\odot$ & 2.488135 & -0.243533 & -0.072328 \\
\hline 16 & 8 & $\odot$ & -3.553616 & ๑. 339767 & 0.039454 \\
\hline 17 & 6 & $\odot$ & -4.492618 & -0.366505 & -0.800672 \\
\hline 18 & 1 & $\odot$ & -4.340256 & -1.440142 & -0.714254 \\
\hline 19 & 1 & $\odot$ & -4.370504 & -0.065257 & -1.838404 \\
\hline 20 & 1 & 0 & -5.470029 & -0.083086 & -0.425610 \\
\hline 21 & 7 & 0 & 3.725109 & -0.885662 & -0.443658 \\
\hline 22 & 8 & $\odot$ & 4.630392 & -0.100344 & -0.780350 \\
\hline 23 & 1 & 0 & $\odot .889118$ & 2.779558 & $\odot .091965$ \\
\hline
\end{tabular}

TS for $\mathbf{4} \rightarrow \mathbf{5}, \mathrm{R}=\mathrm{NO}^{\mathrm{b}} \quad(\mathrm{G}=-664.729242$ Hartrees $)$ 


\begin{tabular}{|c|c|c|c|c|c|}
\hline 1 & 6 & $\odot$ & ๑.718030 & 1.268214 & ๑. 103522 \\
\hline 2 & 6 & $\odot$ & -0.232001 & 2.275009 & ๑. 456719 \\
\hline 3 & 6 & $\odot$ & -1.345374 & ๑.477551 & -0.413924 \\
\hline 4 & 6 & $\odot$ & -0.013304 & 0.066487 & -0.078287 \\
\hline 5 & 1 & $\odot$ & $-\odot .107958$ & 3. 324542 & ๑.197335 \\
\hline 6 & 1 & $\odot$ & - ๑. 890635 & 2.064327 & 1.288186 \\
\hline 7 & 1 & $\odot$ & -1.472300 & 1.162508 & -1.242021 \\
\hline 8 & 6 & $\odot$ & -2.532167 & -0.294646 & $\odot .001773$ \\
\hline 9 & 8 & $\odot$ & -2.496795 & -1.304773 & ๑. 699475 \\
\hline 10 & 6 & $\odot$ & ๑. 613131 & -1.193769 & ๑.010690 \\
\hline 11 & 6 & $\odot$ & 2.117232 & 1.270579 & -0.033825 \\
\hline 12 & 1 & $\odot$ & 2.727303 & 2.167004 & -0.012847 \\
\hline 13 & 6 & $\odot$ & 2.001812 & -1.203025 & ๑.0०2103 \\
\hline 14 & 1 & $\odot$ & 2.556212 & -2.132639 & ๑. 005655 \\
\hline 15 & 6 & $\odot$ & 2.726877 & ๑. 015871 & -0.047796 \\
\hline 16 & 8 & $\odot$ & -3.673598 & ๑.256645 & -0.480327 \\
\hline 17 & 6 & $\odot$ & -4.881196 & -0.439921 & -0.095833 \\
\hline 18 & 1 & $\odot$ & -4.966676 & -0.468996 & ๑.987936 \\
\hline 19 & 1 & $\odot$ & -4.867682 & -1.454160 & -0.487684 \\
\hline 20 & 1 & $\odot$ & -5.687313 & 0.136549 & -0.535475 \\
\hline 21 & 7 & $\odot$ & 4.166114 & ๑.075052 & -0.110335 \\
\hline 22 & 8 & $\odot$ & 4.728773 & -1.035127 & -0.075843 \\
\hline 23 & 1 & $\odot$ & ๑.040952 & -2.112559 & $-\odot .006024$ \\
\hline
\end{tabular}

TS for $\mathbf{4 \rightarrow 6}, \mathrm{R}=\mathrm{COMe}^{\mathrm{a}}(\mathrm{G}=-687.932490$ Hartrees $)$

$\begin{array}{rrrrrr}1 & 6 & 0 & -0.036197 & -0.427659 & 0.858549 \\ 2 & 6 & 0 & -1.103623 & -1.014059 & 1.596036 \\ 3 & 6 & 0 & -1.819980 & -.979231 & 0.594844 \\ 4 & 6 & 0 & -0.394359 & 0.922722 & 0.597208 \\ 5 & 1 & 0 & -1.467868 & -0.477901 & 2.461323 \\ 6 & 1 & 0 & -1.339717 & -2.074905 & 1.544475 \\ 7 & 1 & 0 & -2.373285 & 1.844254 & 0.957283 \\ 8 & 6 & 0 & -2.587348 & 0.100737 & -0.324529 \\ 9 & 8 & 0 & -2.147356 & -0.547228 & -1.266395 \\ 10 & 6 & 0 & 0.593662 & 1.881795 & 0.317834 \\ 11 & 6 & 0 & 1.213602 & -0.926190 & 0.455144 \\ 12 & 1 & 0 & 1.485400 & -1.972645 & 0.530934 \\ 13 & 6 & 0 & 1.869934 & 1.403828 & 0.036105 \\ 14 & 1 & 0 & 2.640411 & 2.110186 & -0.245326 \\ 15 & 6 & 0 & 2.171814 & 0.013019 & 0.069891 \\ 16 & 8 & 0 & -3.918380 & 0.196586 & -0.034392 \\ 17 & 6 & 0 & -4.770653 & -0.561243 & -0.919233 \\ 18 & 1 & 0 & -4.536930 & -1.621558 & -0.850328 \\ 19 & 1 & 0 & -4.640600 & -0.228182 & -1.946368 \\ 20 & 1 & 0 & -5.779232 & -0.364753 & -0.571637 \\ 21 & 1 & 0 & 0.358637 & 2.935427 & 0.214456 \\ 22 & 6 & 0 & 4.504276 & 0.440693 & -0.982314 \\ 23 & 1 & 0 & 4.052326 & 0.873173 & -1.875526 \\ 24 & 1 & 0 & 5.393768 & -0.122196 & -1.252316 \\ 25 & 1 & 0 & 4.785697 & 1.259778 & -0.318681 \\ 26 & 6 & 0 & 3.538270 & -0.493759 & -0.289729 \\ 27 & 8 & 0 & 3.858861 & -1.658779 & -0.037604\end{array}$


TS for $\mathbf{4} \rightarrow \mathbf{5}, \mathrm{R}=\mathrm{COMe}^{\mathrm{a}} \quad(\mathrm{G}=-687.936829$ Hartrees $)$

\begin{tabular}{|c|c|c|c|c|c|}
\hline 1 & 6 & $\odot$ & $\odot .34064 \odot$ & 1.225724 & 0.109583 \\
\hline 2 & 6 & $\odot$ & $-\odot .589140$ & 2.256009 & 0.448253 \\
\hline 3 & 6 & $\odot$ & -1.737169 & 0.462760 & -0.418603 \\
\hline 4 & 6 & $\odot$ & -0.414394 & ๑.036704 & -0.064784 \\
\hline 5 & 1 & $\odot$ & -0.433316 & 3.302020 & 0.191387 \\
\hline 6 & 1 & $\odot$ & -1.263521 & 2.062968 & 1.271503 \\
\hline 7 & 1 & $\odot$ & -1.846762 & 1.142163 & -1.253423 \\
\hline 8 & 6 & $\odot$ & -2.938738 & -0.283842 & -0.003911 \\
\hline 9 & 8 & $\odot$ & -2.929482 & -1.284933 & 0.708113 \\
\hline 10 & 6 & $\odot$ & 0.195787 & -1.223331 & 0.046299 \\
\hline 11 & 6 & $\odot$ & 1.739389 & 1.208837 & -0.013080 \\
\hline 12 & 1 & $\odot$ & 2.347152 & 2.106150 & $\odot .003102$ \\
\hline 13 & 6 & $\odot$ & 1.588785 & -1.241300 & 0.055044 \\
\hline 14 & 1 & $\odot$ & 2.094126 & -2.198076 & $\odot .083876$ \\
\hline 15 & 6 & $\odot$ & 2.356170 & -0.045743 & -0.008529 \\
\hline 16 & 8 & $\odot$ & -4.068282 & 0.278728 & -0.504977 \\
\hline 17 & 6 & $\odot$ & -5.289119 & -0.392753 & -0.120941 \\
\hline 18 & 1 & $\odot$ & -5.385561 & -0.403530 & $\odot .962347$ \\
\hline 19 & 1 & $\odot$ & -5.288511 & -1.413482 & -0.496141 \\
\hline 20 & 1 & $\odot$ & -6.082657 & 0.188644 & -0.576999 \\
\hline 21 & 1 & $\odot$ & -0.380495 & -2.139763 & 0.035554 \\
\hline 22 & 6 & $\odot$ & 4.553033 & -1.424807 & -0.132838 \\
\hline 23 & 1 & $\odot$ & 4.335183 & -2.020075 & 0.754938 \\
\hline 24 & 1 & $\odot$ & 5.623799 & -1.251672 & -0.198575 \\
\hline 25 & 1 & $\odot$ & 4.217223 & -1.988122 & -1.004248 \\
\hline 26 & 6 & $\odot$ & 3.856209 & -0.084829 & -0.060116 \\
\hline 27 & 8 & $\odot$ & 4.509592 & 0.962730 & -0.052084 \\
\hline
\end{tabular}

TS for $\mathbf{4} \rightarrow \mathbf{6}, \mathrm{R}=\mathrm{COMe}^{\mathrm{b}} \quad(\mathrm{G}=-687.933620$ Hartrees $)$

\begin{tabular}{|c|c|c|c|c|c|}
\hline 1 & 6 & $\odot$ & $-\odot .0 \odot 3 \odot \odot 3$ & -0.220413 & $\odot .906604$ \\
\hline 2 & 6 & $\odot$ & -1.047080 & -0.686784 & 1.756058 \\
\hline 3 & 6 & $\odot$ & -1.828049 & 1. 061869 & 0.428323 \\
\hline 4 & 6 & $\odot$ & -0.400761 & 1.049446 & 0.412660 \\
\hline 5 & 1 & $\odot$ & -1.409211 & -0.014408 & 2.521139 \\
\hline 6 & 1 & $\odot$ & -1.261727 & -1.744437 & 1.897098 \\
\hline 7 & 1 & $\odot$ & -2.404322 & 1.961561 & 0.638890 \\
\hline 8 & $\overline{6}$ & $\odot$ & -2.577585 & 0.014089 & -0.311478 \\
\hline 9 & 8 & $\odot$ & -2.125075 & -0.794021 & -1.113386 \\
\hline 10 & 6 & $\odot$ & $\odot .556809$ & 1.969376 & -0.052165 \\
\hline 11 & 6 & $\odot$ & 1.254543 & -0.754661 & 0.570933 \\
\hline 12 & 1 & $\odot$ & 1.521609 & -1.769782 & $\odot .839759$ \\
\hline 13 & $\overline{6}$ & $\odot$ & 1.840036 & 1.482099 & -0.263726 \\
\hline 14 & 1 & $\odot$ & 2.611114 & 2.118040 & -0.679851 \\
\hline 15 & 6 & $\odot$ & 2.181691 & $\odot .127966$ & $\odot .011052$ \\
\hline 16 & 8 & $\odot$ & -3.910572 & 0.141224 & -0.044265 \\
\hline 17 & 6 & $\odot$ & -4.748874 & -0.782624 & -0.770306 \\
\hline 18 & 1 & $\odot$ & $-4.5 \odot \odot \odot 44$ & -1.807327 & -0.502425 \\
\hline 19 & 1 & $\odot$ & -4.620396 & -0.647344 & -1.841742 \\
\hline 20 & 1 & $\odot$ & -5.761282 & -0.539073 & -0.466405 \\
\hline
\end{tabular}




$\begin{array}{rrrrrr}21 & 1 & 0 & 0.288286 & 2.978896 & -0.343284 \\ 22 & 6 & 0 & 3.917139 & -1.783157 & -0.225643 \\ 23 & 1 & 0 & 3.844208 & -2.134602 & 0.804704 \\ 24 & 1 & 0 & 4.935525 & -1.920886 & -0.578882 \\ 25 & 1 & 0 & 3.230854 & -2.374606 & -0.832188 \\ 26 & 6 & 0 & 3.578470 & -0.311631 & -0.308285 \\ 27 & 8 & 0 & 4.433819 & 0.515362 & -0.639972\end{array}$

TS for $\mathbf{4} \rightarrow \mathbf{5}, \mathrm{R}=\mathrm{COMe}^{\mathrm{b}}(\mathrm{G}=-687.936871$ Hartrees $)$

\begin{tabular}{|c|c|c|c|c|c|}
\hline 1 & 6 & $\odot$ & $\odot .373618$ & 1.156010 & ๑.145884 \\
\hline 2 & 6 & $\odot$ & -0.527243 & 2.203759 & ๑. 510991 \\
\hline 3 & 6 & $\odot$ & -1.724259 & 0.479643 & -0.403903 \\
\hline 4 & 6 & $\odot$ & -0.415785 & $-\odot .0 \odot 2 \odot 93$ & -0.065124 \\
\hline 5 & 1 & $\odot$ & -0.342544 & 3. 251425 & ๑. 279661 \\
\hline 6 & 1 & $\odot$ & -1.205694 & 2.011345 & 1.330887 \\
\hline 7 & 1 & $\odot$ & -1.811871 & 1.179893 & -1.224018 \\
\hline 8 & 6 & $\odot$ & -2.950142 & $-\odot .236903$ & -0.006822 \\
\hline 9 & 8 & $\odot$ & -2.975115 & -1.245915 & ๑. 693166 \\
\hline 10 & 6 & $\odot$ & ๑. 154978 & -1.285581 & ๑.0०6293 \\
\hline 11 & 6 & $\odot$ & 1.773780 & 1.098711 & 0.023930 \\
\hline 12 & 1 & $\odot$ & 2.378249 & 1.996571 & $\odot .077094$ \\
\hline 13 & 6 & $\odot$ & 1.543856 & -1.347476 & ๑. 011907 \\
\hline 14 & 1 & $\odot$ & 2.052094 & -2.303411 & $\odot .0 \odot 4770$ \\
\hline 15 & 6 & $\odot$ & 2.349518 & -0.176325 & $-\odot .0 \odot 8584$ \\
\hline 16 & 8 & $\odot$ & -4.059407 & $\odot .365404$ & -0.507771 \\
\hline 17 & 6 & $\odot$ & -5.301750 & $-\odot .275370$ & -0.140341 \\
\hline 18 & 1 & $\odot$ & -5.405773 & $-\odot .297374$ & $\odot .942082$ \\
\hline 19 & 1 & $\odot$ & -5.327931 & -1.290776 & -0.528786 \\
\hline 20 & 1 & $\odot$ & -6.075120 & $\odot .334477$ & -0.593901 \\
\hline 21 & 1 & $\odot$ & $-\odot .450648$ & -2.181995 & -0.035658 \\
\hline 22 & 6 & $\odot$ & 4.719219 & ๑. 866939 & -0.169987 \\
\hline 23 & 1 & $\odot$ & 4.445830 & 1.470141 & -1.036155 \\
\hline 24 & 1 & $\odot$ & 5.750607 & 0.537715 & -0.263155 \\
\hline 25 & 1 & $\odot$ & 4.618128 & 1.490189 & ๑.719734 \\
\hline 26 & 6 & $\odot$ & 3.836218 & $-\odot .356968$ & -0.063636 \\
\hline 27 & 8 & $\odot$ & 4.332349 & -1.487524 & -0.024920 \\
\hline
\end{tabular}

TS for $\mathbf{4} \rightarrow \mathbf{6}, \mathrm{R}=\mathrm{CHO}^{\mathrm{a}}(\mathrm{G}=-648.766385$ Hartrees $)$

$\begin{array}{rrrrrr}1 & 6 & \odot & 0.381169 & -0.266023 & 0.818795 \\ 2 & 6 & 0 & -0.625864 & -0.747018 & 1.701545 \\ 3 & 6 & 0 & -1.449103 & 1.054269 & 0.441064 \\ 4 & 6 & 0 & -0.025016 & 1.023906 & 0.374031 \\ 5 & 1 & 0 & -0.959114 & -0.085479 & 2.489002 \\ 6 & 1 & 0 & -0.835816 & -1.806499 & 1.831581 \\ 7 & 1 & 0 & -2.004515 & 1.956523 & 0.692275 \\ 8 & 6 & 0 & -2.240832 & 0.026634 & -0.283843 \\ 9 & 8 & 0 & -1.832627 & -0.755509 & -1.133340 \\ 10 & 6 & 0 & 0.917730 & 1.953036 & -0.099941 \\ 11 & 6 & 0 & 1.619166 & -0.799748 & 0.422819 \\ 12 & 1 & 0 & 1.924114 & -1.818496 & 0.634668 \\ 13 & 6 & 0 & 2.189062 & 1.460315 & -0.374705\end{array}$




\begin{tabular}{|c|c|c|c|c|c|}
\hline 14 & 1 & $\odot$ & 2.939577 & 2.115204 & -0.805396 \\
\hline 15 & 6 & $\odot$ & 2.521884 & ๑. 097697 & $-0.14760 \odot$ \\
\hline 16 & 8 & $\odot$ & -3.556193 & $\odot .145727$ & ๑. $06 \odot 419$ \\
\hline 17 & 6 & $\odot$ & -4.434681 & $-\odot .757759$ & -0.644445 \\
\hline 18 & 1 & $\odot$ & -4.169519 & -1.789308 & -0.422803 \\
\hline 19 & 1 & $\odot$ & -4.368294 & $-\odot .589217$ & -1.716791 \\
\hline 20 & 1 & $\odot$ & -5.427881 & -0.526099 & $-\odot .275098$ \\
\hline 21 & 1 & $\odot$ & $\odot .644149$ & 2.972106 & -0.349681 \\
\hline 22 & 6 & $\odot$ & 3.884209 & -0.363071 & -0.514117 \\
\hline 23 & 8 & $\odot$ & 4.300985 & -1.505672 & -0.334876 \\
\hline 24 & 1 & $\odot$ & 4.533631 & $\odot .401475$ & -0.976994 \\
\hline
\end{tabular}

TS for $4 \rightarrow 5, R=\mathrm{CHO}^{\mathrm{a}}(\mathrm{G}=-648.770160$ Hartrees $)$

\begin{tabular}{|c|c|c|c|c|c|}
\hline 1 & 6 & $\odot$ & ๑.791665 & 1.063185 & $\odot .126770$ \\
\hline 2 & 6 & $\odot$ & $-\odot .057519$ & 2.149432 & $\odot .497325$ \\
\hline 3 & 6 & $\odot$ & -1.338767 & $\odot .462937$ & $-\odot .406767$ \\
\hline 4 & 6 & $\odot$ & $-\odot .049717$ & $-\odot .06575 \odot$ & $-\odot .069582$ \\
\hline 5 & 1 & $\odot$ & 0.173120 & 3.187248 & ๑. 265369 \\
\hline 6 & 1 & $\odot$ & -0.743100 & 1.984423 & 1.317366 \\
\hline 7 & 1 & $\odot$ & -1.400379 & 1.171338 & -1.222255 \\
\hline 8 & 6 & $\odot$ & -2.590557 & $-\odot .205708$ & $-\odot . \odot \odot 626 \odot$ \\
\hline 9 & 8 & $\odot$ & -2.650992 & -1.223826 & 0.678415 \\
\hline 10 & 6 & $\odot$ & $\odot .460040$ & -1.372985 & 0.011828 \\
\hline 11 & 6 & $\odot$ & 2.184690 & $\odot .947072$ & $-\odot .0 \odot 9699$ \\
\hline 12 & 1 & 0 & 2.860613 & 1.794589 & ๑. 019218 \\
\hline 13 & 6 & $\odot$ & 1.847354 & -1.492545 & $\odot .0 \odot 909 \odot$ \\
\hline 14 & 1 & $\odot$ & 2.301649 & -2.478175 & ๑. 011562 \\
\hline 15 & 6 & $\odot$ & 2.693095 & -0.353813 & -0.035559 \\
\hline 16 & 8 & $\odot$ & -3.676768 & $\odot .450447$ & -0.487126 \\
\hline 17 & 6 & $\odot$ & -4.942785 & -0.141442 & -0.117350 \\
\hline 18 & 1 & $\odot$ & -5.037927 & -0.174908 & $\odot .965545$ \\
\hline 19 & 1 & $\odot$ & -5.016241 & -1.148725 & -0.520519 \\
\hline 20 & 1 & $\odot$ & -5.692601 & $\odot .508283$ & -0.554644 \\
\hline 21 & 1 & $\odot$ & -0.186820 & -2.240468 & -0.015288 \\
\hline 22 & 6 & $\odot$ & 4.159646 & $-\odot .568895$ & $-\odot .095377$ \\
\hline 23 & 8 & $\odot$ & 4.992279 & $\odot .334978$ & -0.140325 \\
\hline 24 & 1 & $\odot$ & 4.482670 & -1.625336 & -0.100592 \\
\hline
\end{tabular}

TS for $\mathbf{4} \rightarrow \mathbf{6}, \mathrm{R}=\mathrm{CHO}^{\mathrm{b}} \quad(\mathrm{G}=-648.767378$ Hartrees $)$

$\begin{array}{rrrrrr}1 & 6 & 0 & 0.287226 & -0.511188 & 0.831392 \\ 2 & 6 & 0 & -0.788849 & -0.992561 & 1.630098 \\ 3 & 6 & 0 & -1.414930 & 0.982917 & 0.564087 \\ 4 & 6 & 0 & 0.004963 & 0.845681 & 0.520522 \\ 5 & 1 & 0 & -1.082619 & -0.399393 & 2.484752 \\ 6 & 1 & 0 & -1.100094 & -2.035287 & 1.631051 \\ 7 & 1 & 0 & -1.905255 & 1.894127 & 0.903409 \\ 8 & 6 & 0 & -2.262231 & 0.115664 & -0.295899 \\ 9 & 8 & 0 & -1.889293 & -0.614133 & -1.206126 \\ 10 & 6 & 0 & 1.035370 & 1.737787 & 0.165382 \\ 11 & 6 & 0 & 1.492670 & -1.097114 & 0.403253 \\ 12 & 1 & 0 & 1.693341 & -2.158614 & 0.515039\end{array}$




$\begin{array}{rrrrrr}13 & 6 & 0 & 2.270246 & 1.179171 & -\odot .136127 \\ 14 & 1 & 0 & 3.092049 & 1.795288 & -\odot .480201 \\ 15 & 6 & 0 & 2.482480 & -0.224043 & -0.048457 \\ 16 & 8 & 0 & -3.575414 & 0.325596 & 0.010383 \\ 17 & 6 & 0 & -4.500196 & -0.412771 & -0.816813 \\ 18 & 1 & 0 & -4.341890 & -1.482264 & -0.695653 \\ 19 & 1 & 0 & -4.369339 & -0.143404 & -1.862283 \\ 20 & 1 & 0 & -5.48366 \odot & -0.124924 & -0.461223 \\ 21 & 1 & 0 & 0.850517 & 2.796761 & 0.023006 \\ 22 & 6 & 0 & 3.797031 & -0.788947 & -0.431981 \\ 23 & 8 & 0 & 4.758714 & -0.119026 & -0.804878 \\ 24 & 1 & 0 & 3.872221 & -1.889369 & -0.365682\end{array}$

TS for $4 \rightarrow \mathbf{5}, \mathrm{R}=\mathrm{CHO}^{\mathrm{b}} \quad(\mathrm{G}=-648.770639$ Hartrees $)$

\begin{tabular}{|c|c|c|c|c|c|}
\hline 1 & 6 & $\odot$ & $\odot .695460$ & 1.265735 & ๑.106733 \\
\hline 2 & 6 & $\odot$ & -0.254273 & 2.274245 & ๑. 455710 \\
\hline 3 & 6 & $\odot$ & -1.368139 & ๑.473917 & -0.414644 \\
\hline 4 & 6 & $\odot$ & -0.035805 & ๑.064054 & -0.075035 \\
\hline 5 & 1 & $\odot$ & $-\odot .125367$ & 3.324178 & ๑. 199244 \\
\hline 6 & 1 & $\odot$ & $-\odot .917462$ & 2.065235 & 1.283977 \\
\hline 7 & 1 & $\odot$ & -1.494253 & 1.153374 & -1.247238 \\
\hline 8 & 6 & $\odot$ & -2.555230 & -0.294932 & ๑. 003855 \\
\hline 9 & 8 & $\odot$ & -2.524492 & -1.293929 & ๑.717783 \\
\hline 10 & 6 & $\odot$ & ๑.592477 & -1.192716 & ๑.017981 \\
\hline 11 & 6 & $\odot$ & 2.095707 & 1.267293 & -0.026354 \\
\hline 12 & 1 & $\odot$ & 2.680671 & 2.182335 & $-\odot .0 \odot 30 \odot 4$ \\
\hline 13 & 6 & $\odot$ & 1.982434 & -1.194041 & ๑.013160 \\
\hline 14 & 1 & $\odot$ & 2.537105 & -2.124513 & ๑.021542 \\
\hline 15 & 6 & $\odot$ & 2.720806 & ๑. 017963 & -0.038314 \\
\hline 16 & 8 & $\odot$ & -3.695500 & 0.245866 & -0.495574 \\
\hline 17 & 6 & $\odot$ & -4.903134 & $-\odot .448659$ & -0.109227 \\
\hline 18 & 1 & $\odot$ & -4.997464 & -0.460492 & ๑.974196 \\
\hline 19 & 1 & $\odot$ & -4.883200 & -1.469297 & -0.483965 \\
\hline 20 & 1 & $\odot$ & -5.708119 & 0.117284 & -0.564548 \\
\hline 21 & 1 & $\odot$ & ๑.024407 & -2.114090 & ๑. 001017 \\
\hline 22 & 6 & $\odot$ & 4.199686 & $-\odot .026727$ & -0.101808 \\
\hline 23 & 8 & $\odot$ & 4.865894 & -1.060677 & -0.099191 \\
\hline 24 & 1 & $\odot$ & 4.696537 & ๑. 959126 & - ๑. 157715 \\
\hline
\end{tabular}

TS for 4 $\rightarrow$ 6, $R=\mathrm{NO}_{2} \quad(\mathrm{G}=-739.755158$ Hartrees $)$

\begin{tabular}{|c|c|c|c|c|c|}
\hline 1 & 6 & $\odot$ & $\odot .021415$ & $-\odot .396097$ & $\odot .854604$ \\
\hline 2 & 6 & $\odot$ & -1.027091 & -0.965678 & 1.628038 \\
\hline 3 & 6 & $\odot$ & -1.770939 & $\odot .994211$ & $\odot .576477$ \\
\hline 4 & 6 & $\odot$ & $-\odot .345872$ & 0.944921 & $\odot .56 \odot 8 \odot 7$ \\
\hline 5 & 1 & $\odot$ & -1.384184 & $-\odot .40 \odot 887$ & 2.477727 \\
\hline 6 & 1 & $\odot$ & -1.257305 & -2.028562 & 1.614244 \\
\hline 7 & 1 & $\odot$ & -2.323719 & 1.867311 & $\odot .919414$ \\
\hline 8 & 6 & $\odot$ & -2.545659 & ๑. 081364 & -0.306783 \\
\hline 9 & 8 & $\odot$ & -2.108564 & -0.596224 & -1.228336 \\
\hline 10 & 6 & $\odot$ & $\odot .630341$ & 1.903856 & ๑.237016 \\
\hline 11 & 6 & $\odot$ & 1.266898 & -0.906677 & $\odot .442788$ \\
\hline 12 & 1 & $\odot$ & 1.553144 & -1.944864 & $\odot .545636$ \\
\hline
\end{tabular}




$\begin{array}{rrrrrr}13 & 6 & 0 & 1.904678 & 1.434434 & -0.061055 \\ 14 & 1 & 0 & 2.685774 & 2.102603 & -0.394659 \\ 15 & 6 & 0 & 2.176468 & 0.049127 & 0.017727 \\ 16 & 8 & 0 & -3.871236 & 0.184747 & -0.007273 \\ 17 & 6 & 0 & -4.732833 & -0.603808 & -0.857618 \\ 18 & 1 & 0 & -4.494792 & -1.660401 & -0.756416 \\ 19 & 1 & 0 & -4.614968 & -0.302971 & -1.895924 \\ 20 & 1 & 0 & -5.737261 & -0.397848 & -0.504158 \\ 21 & 7 & 0 & 3.527457 & -0.403661 & -0.363072 \\ 22 & 8 & 0 & 3.864101 & -1.555867 & -0.036695 \\ 23 & 8 & 0 & 4.244347 & 0.395387 & -0.993880 \\ 24 & 1 & 0 & 0.387490 & 2.952987 & 0.113111\end{array}$

TS for $\mathbf{4} \rightarrow \mathbf{5}, \mathrm{R}=\mathrm{NO}_{2} \quad(\mathrm{G}=-\mathbf{7 3 9} .758856$ Hartrees $)$

\begin{tabular}{|c|c|c|c|c|c|}
\hline 1 & 6 & $\odot$ & $\odot .4 \odot 4 \odot 43$ & 1.187844 & $\odot .180794$ \\
\hline 2 & 6 & $\odot$ & -0.503939 & 2.210735 & $\odot .586949$ \\
\hline 3 & 6 & $\odot$ & -1.685718 & 0.494960 & -0.391126 \\
\hline 4 & 6 & $\odot$ & -0.370545 & ๑. 025192 & -0.067373 \\
\hline 5 & 1 & $\odot$ & -0.328254 & 3.267653 & $\odot .398539$ \\
\hline 6 & 1 & $\odot$ & -1.187513 & 1.974802 & 1.390925 \\
\hline 7 & 1 & $\odot$ & -1.784172 & 1.229173 & -1.179699 \\
\hline 8 & 6 & $\odot$ & -2.898889 & $-\odot .258648$ & -0.019529 \\
\hline 9 & 8 & $\odot$ & -2.897210 & -1.306182 & $\odot .621789$ \\
\hline 10 & 6 & $\odot$ & ๑. 212815 & -1.253668 & -0.039794 \\
\hline 11 & 6 & $\odot$ & 1.805163 & 1.158780 & $\odot .051115$ \\
\hline 12 & 1 & $\odot$ & 2.434350 & 2.036455 & $\odot .119209$ \\
\hline 13 & 6 & $\odot$ & 1.603644 & -1.309792 & -0.035602 \\
\hline 14 & 1 & $\odot$ & 2.127123 & -2.254785 & -0.071785 \\
\hline 15 & 6 & $\odot$ & 2.353900 & $-\odot .113801$ & -0.026520 \\
\hline 16 & 8 & $\odot$ & $-4.01923 \odot$ & $\odot .353957$ & $-\odot .474045$ \\
\hline 17 & 6 & $\odot$ & -5.250650 & -0.323624 & -0.132472 \\
\hline 18 & 1 & $\odot$ & -5.342313 & $-\odot .409237$ & $\odot .947756$ \\
\hline 19 & 1 & $\odot$ & -5.267163 & -1.314619 & $-\odot .579684$ \\
\hline 20 & 1 & $\odot$ & -6.035528 & ๑. 301840 & -0.542452 \\
\hline 21 & 7 & $\odot$ & 3.821965 & $-\odot .228284$ & -0.081112 \\
\hline 22 & 8 & $\odot$ & 4.465571 & $\odot .782307$ & -0.417147 \\
\hline 23 & 8 & $\odot$ & 4.325080 & -1.328435 & 0.214079 \\
\hline 24 & 1 & $\odot$ & -0.382906 & -2.154336 & -0.111063 \\
\hline
\end{tabular}

7, $\mathrm{R}=\mathrm{CN}(\mathrm{G}=-627.813754$ Hartrees $)$

$\begin{array}{rrrrrr}1 & 6 & \odot & 0.440030 & -1.659258 & 0.019340 \\ 2 & 6 & 0 & -0.957358 & -2.193626 & 0.292990 \\ 3 & 6 & 0 & -1.305668 & -0.750157 & 0.801928 \\ 4 & 6 & 0 & 0.129334 & -0.371481 & 0.462971 \\ 5 & 1 & 0 & -1.026995 & -2.967057 & 1.059123 \\ 6 & 1 & 0 & -1.534516 & -2.490635 & -0.582457 \\ 7 & 1 & 0 & -1.548445 & -0.681929 & 1.865500 \\ 8 & 6 & \odot & -2.346292 & -0.004211 & 0.006406 \\ 9 & 8 & \odot & -3.092170 & -0.484986 & -0.834215 \\ 10 & 6 & \odot & 1.034943 & 0.678532 & 0.466702 \\ 11 & 6 & 0 & 1.710717 & -1.993831 & -0.437940 \\ 12 & 1 & 0 & 1.979089 & -2.985832 & -0.781389\end{array}$




$\begin{array}{rrrrrr}13 & 6 & \odot & 2.323106 & 0.345601 & -0.005529 \\ 14 & 6 & 0 & 2.653497 & -0.955416 & -0.449951 \\ 15 & 8 & 0 & -2.33209 \odot & 1.307153 & 0.348946 \\ 16 & 6 & 0 & -3.283085 & 2.127994 & -0.369604 \\ 17 & 1 & 0 & -4.293563 & 1.766305 & -0.196058 \\ 18 & 1 & 0 & -3.063883 & 2.105495 & -1.434327 \\ 19 & 1 & 0 & -3.151353 & 3.125700 & 0.033648 \\ 20 & 1 & \odot & 0.80069 \odot & 1.681214 & 0.802607 \\ 21 & 6 & 0 & 3.336442 & 1.364563 & -0.045969 \\ 22 & 7 & \odot & 4.165322 & 2.211014 & -0.076028 \\ 23 & 1 & 0 & 3.661802 & -1.139954 & -0.800363\end{array}$

7, $\mathrm{R}=\mathrm{NO}^{\mathrm{a}}(\mathrm{G}=-664.786279$ Hartrees $)$

\begin{tabular}{|c|c|c|c|c|c|}
\hline 1 & 6 & $\odot$ & -0.425207 & 1.593724 & $\odot .033601$ \\
\hline 2 & 6 & $\odot$ & 0.952041 & 2.194460 & $\odot .267260$ \\
\hline 3 & 6 & $\odot$ & 1.377481 & 0.777253 & ๑.789842 \\
\hline 4 & 6 & 0 & $-\odot .045843$ & ๑. 327965 & ๑. 486817 \\
\hline 5 & 1 & $\odot$ & 1.003462 & 2.983412 & 1.019012 \\
\hline 6 & 1 & $\odot$ & 1.494344 & 2.502770 & -0.626467 \\
\hline 7 & 1 & $\odot$ & 1.644945 & 0.736579 & 1.848765 \\
\hline 8 & 6 & $\odot$ & 2.432760 & ๑.067032 & -0.018432 \\
\hline 9 & 8 & 0 & 3.121870 & ๑.562166 & -0.898481 \\
\hline 10 & 6 & $\odot$ & -0.909018 & $-\odot .757944$ & $\odot .517223$ \\
\hline 11 & 6 & 0 & -1.720141 & 1.868385 & -0.408633 \\
\hline 12 & 1 & $\odot$ & -2.030934 & 2.845774 & -0.758773 \\
\hline 13 & 6 & $\odot$ & -2.211122 & -0.478332 & 0.064470 \\
\hline 14 & 6 & $\odot$ & -2.617463 & $\odot .794722$ & $-\odot .3890 \odot 7$ \\
\hline 15 & 8 & $\odot$ & 2.503413 & -1.232252 & $\odot .360855$ \\
\hline 16 & 6 & $\odot$ & 3.470911 & -2.021728 & $-0.37036 \odot$ \\
\hline 17 & 1 & $\odot$ & 4.466194 & -1.602869 & $-\odot .243703$ \\
\hline 18 & 1 & $\odot$ & 3.213387 & -2.040694 & -1.426553 \\
\hline 19 & 1 & $\odot$ & 3.406964 & -3.013255 & $\odot .063428$ \\
\hline 20 & 1 & $\odot$ & $-\odot .647671$ & -1.753627 & $\odot .855554$ \\
\hline 21 & 7 & $\odot$ & -3.097214 & -1.616653 & $\odot .103849$ \\
\hline 22 & 8 & $\odot$ & -4.257156 & -1.386165 & -0.284314 \\
\hline 23 & 1 & $\odot$ & -3.641607 & 0.915267 & $-\odot .719371$ \\
\hline
\end{tabular}

7, $\mathrm{R}=\mathrm{NO}^{\mathrm{b}} \quad(\mathrm{G}=-664.786771$ Hartrees $)$

\begin{tabular}{|c|c|c|c|c|c|}
\hline 1 & 6 & $\odot$ & ๑. 457862 & -1.704045 & 0.048753 \\
\hline 2 & 6 & $\odot$ & -0.934235 & -2.232221 & $\odot .357043$ \\
\hline 3 & 6 & $\odot$ & -1.284387 & -0.775446 & 0.821496 \\
\hline 4 & 6 & $\odot$ & 0.144848 & -0.397990 & 0.450750 \\
\hline 5 & 1 & $\odot$ & -0.991841 & -2.981340 & 1.148001 \\
\hline 6 & 1 & $\odot$ & -1.518368 & -2.559985 & -0.502800 \\
\hline 7 & 1 & $\odot$ & -1.512863 & $-\odot .670856$ & 1.885036 \\
\hline 8 & 6 & $\odot$ & -2.336224 & $-\odot .061501$ & 0.011931 \\
\hline 9 & 8 & $\odot$ & -3.058625 & -0.565431 & $-\odot .835899$ \\
\hline 10 & 6 & $\odot$ & 1.037783 & 0.658250 & 0.406027 \\
\hline 11 & 6 & 0 & 1.720824 & -2.053506 & -0.418103 \\
\hline 12 & 1 & 0 & 1.985825 & -3.057080 & $-\odot .728580$ \\
\hline 13 & 6 & 0 & 2.313126 & 0.301185 & $-\odot .076719$ \\
\hline 14 & 6 & 0 & 2.652574 & -1.006054 & -0.476608 \\
\hline
\end{tabular}




$\begin{array}{rrrrrr}15 & 8 & 0 & -2.358353 & 1.251568 & 0.345851 \\ 16 & 6 & 0 & -3.312800 & 2.046558 & -0.396462 \\ 17 & 1 & 0 & -4.318754 & 1.665934 & -0.237619 \\ 18 & 1 & 0 & -3.074206 & 2.019496 & -1.456922 \\ 19 & 1 & 0 & -3.208208 & 3.050101 & 0.000200 \\ 20 & 1 & 0 & 0.815352 & 1.674076 & 0.707015 \\ 21 & 7 & 0 & 3.400 \odot 49 & 1.238208 & -0.209058 \\ 22 & 8 & 0 & 3.117366 & 2.402882 & 0.128983 \\ 23 & 1 & 0 & 3.663393 & -1.171313 & -0.831059\end{array}$

7, $\mathrm{R}=\mathrm{COMe}^{\mathrm{a}}(\mathrm{G}=-687.994348$ Hartrees $)$

\begin{tabular}{|c|c|c|c|c|c|}
\hline 1 & 6 & $\odot$ & -0.080621 & 1.807587 & -0.062529 \\
\hline 2 & 6 & $\odot$ & -1.521452 & 2.213758 & -0.330829 \\
\hline 3 & 6 & 0 & -1.751198 & 0.734817 & -0.802878 \\
\hline 4 & 6 & $\odot$ & -0.281847 & 0.488383 & -0.478525 \\
\hline 5 & 1 & 0 & -1.664608 & 2.959335 & -1.114479 \\
\hline 6 & 1 & $\odot$ & -2.112715 & 2.481753 & 0.544687 \\
\hline 7 & 1 & 0 & -2.003817 & 0.618400 & -1.859661 \\
\hline 8 & 6 & $\odot$ & -2.701947 & - ๑. . 081915 & ๑.032811 \\
\hline 9 & 8 & $\odot$ & -3.408736 & 0.334967 & 0.939593 \\
\hline 10 & 6 & $\odot$ & 0.710544 & -0.477395 & -0.476900 \\
\hline 11 & 6 & $\odot$ & 1.164882 & 2.256511 & $\odot .361000$ \\
\hline 12 & 1 & $\odot$ & 1.354566 & 3.273833 & $\odot .683287$ \\
\hline 13 & 6 & 0 & 1.978828 & -0.038785 & $-\odot .039077$ \\
\hline 14 & 6 & $\odot$ & 2.189302 & 1.295438 & $\odot .377025$ \\
\hline 15 & 8 & $\odot$ & -2.646683 & -1.381419 & -0.348634 \\
\hline 16 & 6 & $\odot$ & -3.485763 & -2.272308 & 0.422116 \\
\hline 17 & 1 & $\odot$ & -4.526984 & -1.970190 & ๑. 339138 \\
\hline 18 & 1 & 0 & -3.182845 & -2.258095 & 1.466360 \\
\hline 19 & 1 & 0 & -3.327825 & -3.251929 & -0.014819 \\
\hline 20 & 1 & $\odot$ & $\odot .567851$ & -1.504418 & -0.788956 \\
\hline 21 & 6 & $\odot$ & 3.087638 & -1.045641 & -0.001657 \\
\hline 22 & 1 & 0 & 3.175041 & 1.596462 & 0.708387 \\
\hline 23 & 8 & $\odot$ & 2.861087 & -2.232564 & -0.259635 \\
\hline 24 & 6 & $\odot$ & 4.488126 & -0.591490 & 0.346836 \\
\hline 25 & 1 & 0 & 4.826493 & 0.183540 & -0.341784 \\
\hline 26 & 1 & 0 & 4.519429 & -0.179998 & 1.356484 \\
\hline 27 & 1 & $\odot$ & 5.151121 & -1.450323 & 0.286407 \\
\hline
\end{tabular}

7, $\mathrm{R}=\mathrm{COMe}^{\mathrm{b}}(\mathrm{G}=-687.994759$ Hartrees $)$

$\begin{array}{rrrrrr}1 & 6 & 0 & -0.093305 & -1.844247 & 0.067677 \\ 2 & 6 & 0 & -1.543574 & -2.209697 & 0.345206 \\ 3 & 6 & 0 & -1.729411 & -0.721787 & 0.809141 \\ 4 & 6 & 0 & -0.258525 & -0.517658 & 0.467549 \\ 5 & 1 & 0 & -1.704809 & -2.946890 & 1.133260 \\ 6 & 1 & 0 & -2.146671 & -2.466273 & -0.525665 \\ 7 & 1 & 0 & -1.966598 & -0.59590 \odot & 1.868883 \\ 8 & 6 & 0 & -2.676161 & -.112190 & -0.013041 \\ 9 & 8 & 0 & -3.457682 & -0.300001 & -0.857854 \\ 10 & 6 & 0 & 0.761648 & 0.423072 & 0.448862 \\ 11 & 6 & 0 & 1.138845 & -2.329760 & -0.363543 \\ 12 & 1 & 0 & 1.298665 & -3.355581 & -0.674892 \\ 13 & 6 & 0 & 2.013819 & -0.054079 & 0.005359 \\ 14 & 6 & 0 & 2.185728 & -1.399149 & -0.393987\end{array}$




$\begin{array}{rrrrrr}15 & 8 & \odot & -2.530804 & 1.423721 & \odot .306439 \\ 16 & 6 & \odot & -3.383122 & 2.321235 & -\odot .441989 \\ 17 & 1 & \odot & -4.427807 & 2.067814 & -\odot .278730 \\ 18 & 1 & \odot & -3.153325 & 2.255847 & -1.502851 \\ 19 & 1 & \odot & -3.157410 & 3.308863 & -\odot .055398 \\ 20 & 1 & \odot & 0.610133 & 1.449354 & \odot .758685 \\ 21 & 6 & \odot & 3.206517 & 0.849792 & -\odot .074428 \\ 22 & 1 & \odot & 3.174135 & -1.694805 & -\odot .723534 \\ 23 & 8 & \odot & 4.313378 & 0.409063 & -\odot .400723 \\ 24 & 6 & \odot & 3.029516 & 2.317208 & \odot .248404 \\ 25 & 1 & \odot & 2.282435 & 2.769094 & -0.405197 \\ 26 & 1 & \odot & 2.695244 & 2.446862 & 1.278684 \\ 27 & 1 & \odot & 3.985021 & 2.816641 & \odot .112610\end{array}$

7, $\mathrm{R}=\mathrm{CHO}^{\mathrm{a}}(\mathrm{G}=-648.828169$ Hartrees $)$

\begin{tabular}{|c|c|c|c|c|c|}
\hline 1 & 6 & $\odot$ & $\odot .399640$ & -1.727159 & $\odot .047919$ \\
\hline 2 & 6 & $\odot$ & -1.002232 & -2.225956 & ๑. 361726 \\
\hline 3 & 6 & $\odot$ & -1.319873 & -0.760140 & $\odot .822175$ \\
\hline 4 & 6 & $\odot$ & $\odot .118372$ & -0.416846 & $\odot .452092$ \\
\hline 5 & 1 & $\odot$ & -1.072168 & -2.969251 & 1.157286 \\
\hline 6 & 1 & $\odot$ & -1.597130 & -2.545573 & -0.493751 \\
\hline 7 & 1 & $\odot$ & -1.548869 & -0.646748 & 1.884668 \\
\hline 8 & 6 & $\odot$ & -2.351352 & $-\odot .024023$ & ๑. 006891 \\
\hline 9 & 8 & $\odot$ & -3.069007 & -0.507942 & -0.856846 \\
\hline 10 & 6 & $\odot$ & 1.041413 & 0.614613 & $\odot .408705$ \\
\hline 11 & 6 & $\Theta$ & 1.657139 & -2.103489 & -0.411414 \\
\hline 12 & 1 & $\odot$ & 1.901364 & -3.112262 & -0.723008 \\
\hline 13 & 6 & $\odot$ & 2.316440 & ๑. 243759 & -0.066640 \\
\hline 14 & 6 & $\Theta$ & 2.611741 & -1.075541 & -0.469432 \\
\hline 15 & 8 & $\Theta$ & -2.359462 & 1.286093 & $\odot .353560$ \\
\hline 16 & 6 & $\odot$ & -3.287503 & 2.103036 & -0.397543 \\
\hline 17 & 1 & $\odot$ & -4.302439 & 1.738488 & -0.259040 \\
\hline 18 & 1 & $\odot$ & -3.031634 & 2.080854 & -1.454119 \\
\hline 19 & 1 & $\odot$ & -3.172631 & 3.101402 & ๑.009286 \\
\hline 20 & 1 & $\odot$ & $\odot .842233$ & 1.635456 & $\odot .711913$ \\
\hline 21 & 6 & $\odot$ & 3.386901 & 1.260844 & -0.171037 \\
\hline 22 & 1 & $\odot$ & 3.613442 & -1.293242 & $-\odot .826850$ \\
\hline 23 & 8 & $\odot$ & 3.252006 & 2.445126 & $\odot .134082$ \\
\hline 24 & 1 & $\odot$ & 4.355419 & $\odot .890 \odot 49$ & $-\odot .553401$ \\
\hline
\end{tabular}

7, $\mathrm{R}=\mathrm{CHO}^{\mathrm{b}} \quad(\mathrm{G}=-648.827854$ Hartrees $)$

$\begin{array}{rrrrrr}1 & 6 & \odot & -\odot .380521 & 1.618443 & \odot .027624 \\ 2 & 6 & \odot & 1.0 \odot 749 \odot & 2.192974 & 0.265891 \\ 3 & 6 & \odot & 1.404274 & \odot .766716 & \odot .787136 \\ 4 & 6 & \odot & -\odot .027377 & 0.345987 & 0.481377 \\ 5 & 1 & \odot & 1.071847 & 2.978572 & 1.020232 \\ 6 & 1 & \odot & 1.559363 & 2.493476 & -0.624645 \\ 7 & 1 & \odot & 1.669679 & \odot .720434 & 1.846572 \\ 8 & 6 & \odot & 2.448888 & 0.038620 & -\odot .017881 \\ 9 & 8 & \odot & 3.159187 & \odot .523038 & -0.886918 \\ 10 & 6 & \odot & -\odot .914413 & -\odot .720861 & 0.518111 \\ 11 & 6 & \odot & -1.671369 & 1.917360 & -0.405945\end{array}$




$\begin{array}{rrrrrr}12 & 1 & 0 & -1.966942 & 2.899601 & -0.755822 \\ 13 & 6 & 0 & -2.218689 & -0.428864 & 0.072405 \\ 14 & 6 & 0 & -2.585807 & 0.856723 & -0.382323 \\ 15 & 8 & 0 & 2.486576 & -1.266619 & 0.350605 \\ 16 & 6 & 0 & 3.446925 & -2.068368 & -0.375896 \\ 17 & 1 & 0 & 4.448628 & -1.669607 & -0.235440 \\ 18 & 1 & 0 & 3.201472 & -2.074764 & -1.435182 \\ 19 & 1 & 0 & 3.360205 & -3.061983 & 0.049368 \\ 20 & 1 & 0 & -0.645397 & -1.713570 & 0.864475 \\ 21 & 6 & 0 & -3.22320 \odot & -1.517169 & 0.069837 \\ 22 & 1 & 0 & -3.608729 & 0.999150 & -0.710385 \\ 23 & 8 & 0 & -4.389696 & -1.392257 & -0.300579 \\ 24 & 1 & 0 & -2.855867 & -2.493984 & 0.433953\end{array}$

7, $\mathrm{R}=\mathrm{NO}_{2} \quad(\mathrm{G}=-739.816446$ Hartrees $)$

\begin{tabular}{|c|c|c|c|c|c|}
\hline 1 & 6 & $\odot$ & ๑. $0 \odot 1859$ & 1.801907 & $\odot .028983$ \\
\hline 2 & 6 & $\odot$ & 1.436311 & 2.233055 & ๑. 293254 \\
\hline 3 & 6 & $\odot$ & 1.682223 & 0.768094 & $\odot .799798$ \\
\hline 4 & 6 & $\odot$ & ๑. 222980 & ๑. 493124 & $\odot .464677$ \\
\hline 5 & 1 & $\odot$ & 1.568088 & 2.999750 & 1.057862 \\
\hline 6 & 1 & $\odot$ & 2.026371 & 2.486318 & -0.587269 \\
\hline 7 & 1 & $\odot$ & 1.920883 & ๑. 681316 & 1.862824 \\
\hline 8 & 6 & 0 & 2.661939 & $-\odot .052599$ & $\odot .0 \odot \odot 106$ \\
\hline 9 & 8 & $\odot$ & 3.428812 & $\odot .370618$ & -0.852470 \\
\hline 10 & 6 & $\odot$ & -0.749004 & $-\odot .497161$ & 0.466786 \\
\hline 11 & 6 & $\odot$ & -1.245060 & 2.223938 & -0.421662 \\
\hline 12 & 1 & $\odot$ & -1.446216 & 3.231573 & -0.765011 \\
\hline 13 & 6 & $\odot$ & -1.995042 & -0.051234 & ๑.006407 \\
\hline 14 & 6 & 0 & -2.260919 & 1.255700 & -0.428702 \\
\hline 15 & 8 & 0 & 2.560756 & -1.356628 & ๑.353349 \\
\hline 16 & 6 & $\odot$ & 3.439502 & -2.248750 & -0.372620 \\
\hline 17 & 1 & $\odot$ & 4.476009 & -1.962112 & -0.212962 \\
\hline 18 & 1 & $\odot$ & 3. 208912 & -2.214185 & -1.434566 \\
\hline 19 & 1 & $\odot$ & 3.238860 & -3.232144 & 0.037203 \\
\hline 20 & 1 & $\odot$ & -0.594345 & -1.518569 & $\odot .785839$ \\
\hline 21 & 7 & $\odot$ & -3.100855 & -1.022577 & -0.034052 \\
\hline 22 & 8 & $\odot$ & -2.802514 & -2.230940 & $\odot .0 \odot 4478$ \\
\hline 23 & 8 & $\odot$ & -4.262109 & -0.578929 & -0.101082 \\
\hline 24 & 1 & $\odot$ & -3.260878 & 1.496680 & -0.761923 \\
\hline
\end{tabular}

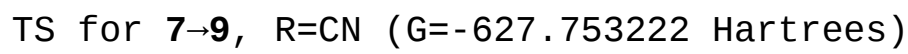

$\begin{array}{rrrrrr}1 & 6 & 0 & -0.206437 & 1.246650 & 0.311338 \\ 2 & 6 & 0 & 0.951036 & 1.794238 & 0.929834 \\ 3 & 6 & 0 & 1.081642 & -0.537310 & 0.932701 \\ 4 & 6 & 0 & -0.263190 & -0.128454 & 0.667201 \\ 5 & 1 & 0 & 1.099676 & 1.598263 & 1.982589 \\ 6 & 1 & 0 & 1.509084 & 2.625723 & 0.504571 \\ 7 & 1 & 0 & 1.329790 & -1.266525 & 1.702101 \\ 8 & 6 & 0 & 2.106826 & -0.390288 & -0.131745 \\ 9 & 8 & 0 & 1.919760 & -0.077308 & -1.301387 \\ 10 & 6 & 0 & -1.472172 & -0.834526 & 0.629165 \\ 11 & 6 & 0 & -1.227746 & 1.824186 & -0.469604\end{array}$




\begin{tabular}{|c|c|c|c|c|c|}
\hline 12 & 1 & $\odot$ & -1.151434 & 2.831926 & $-\odot .860861$ \\
\hline 13 & 6 & $\odot$ & -2.534026 & $-\odot .203561$ & -0.031314 \\
\hline 14 & 6 & $\odot$ & -2.400957 & 1.094305 & -0.603239 \\
\hline 15 & 8 & $\odot$ & 3. 323984 & -0.753628 & 0.364827 \\
\hline 16 & 6 & $\odot$ & 4.393517 & -0.715444 & -0.604790 \\
\hline 17 & 1 & $\odot$ & 4.523396 & ๑. 296802 & -0.981575 \\
\hline 18 & 1 & $\odot$ & 4.175155 & -1.385367 & -1.433081 \\
\hline 19 & 1 & $\odot$ & 5.273865 & -1.042031 & $-\odot .061937$ \\
\hline 20 & 1 & $\odot$ & -1.566199 & -1.856197 & $\odot .979665$ \\
\hline 21 & 6 & $\odot$ & -3.785806 & -0.892658 & -0.170732 \\
\hline 22 & 7 & 0 & -4.821989 & -1.458587 & -0.279200 \\
\hline 23 & 1 & $\odot$ & -3.245494 & 1.512175 & -1.137486 \\
\hline
\end{tabular}

TS for $\mathbf{7} \rightarrow \mathbf{8}, \mathrm{R}=\mathrm{CN}(\mathrm{G}=-627.756262$ Hartrees )

\begin{tabular}{|c|c|c|c|c|c|}
\hline 1 & 6 & $\odot$ & 0.661746 & 1.771967 & 0.182642 \\
\hline 2 & 6 & $\odot$ & $-\odot .407078$ & 2.639507 & 0.555284 \\
\hline 3 & 6 & $\odot$ & -1.268550 & 0.837287 & $-\odot .580705$ \\
\hline 4 & 6 & $\odot$ & $\odot .075760$ & 0.527902 & -0.173151 \\
\hline 5 & 1 & $\odot$ & -0.374363 & 3.717808 & 0.413719 \\
\hline 6 & 1 & $\odot$ & -1.115028 & 2.275044 & 1.287078 \\
\hline 7 & 1 & $\odot$ & -1.396747 & 1.581461 & -1.355874 \\
\hline 8 & 6 & $\odot$ & -2.448015 & $-\odot .016892$ & -0.354240 \\
\hline 9 & 8 & $\odot$ & -3.570089 & ๑. 212113 & -0.795999 \\
\hline 10 & 6 & $\odot$ & ๑. 829371 & -0.652541 & -0.166710 \\
\hline 11 & 6 & $\odot$ & 2.060845 & 1.937821 & 0.156708 \\
\hline 12 & 1 & $\odot$ & 2.528264 & 2.903543 & $\odot .311112$ \\
\hline 13 & 6 & $\odot$ & 2.217927 & $-\odot .497624$ & -0.056248 \\
\hline 14 & 6 & $\odot$ & 2.827400 & $\odot .782129$ & $\odot .068014$ \\
\hline 15 & 8 & $\odot$ & -2.146316 & -1.083901 & 0.434191 \\
\hline 16 & 6 & $\odot$ & -3.261014 & -1.969830 & 0.686668 \\
\hline 17 & 1 & $\odot$ & -3.640997 & -2.369344 & -0.250689 \\
\hline 18 & 1 & $\odot$ & -4.053854 & -1.432202 & 1.201296 \\
\hline 19 & 1 & $\odot$ & -2.855465 & -2.758048 & 1.311244 \\
\hline 20 & 1 & $\odot$ & $\odot .387424$ & -1.626966 & -0.331592 \\
\hline 21 & 6 & $\odot$ & 3.059132 & -1.660157 & -0.110573 \\
\hline 22 & 7 & $\odot$ & 3.751228 & -2.622073 & -0.149710 \\
\hline 23 & 1 & $\odot$ & 3.908265 & $\odot .840102$ & $\odot .109999$ \\
\hline
\end{tabular}

TS for $\mathbf{7 \rightarrow 9}, \mathrm{R}=\mathrm{NO}^{\mathrm{a}} \quad(\mathrm{G}=-664.726156$ Hartrees $)$

\begin{tabular}{|c|c|c|c|c|c|}
\hline 1 & 6 & $\odot$ & -0.166855 & 1.288843 & $\odot .368983$ \\
\hline 2 & 6 & 0 & ๑.982048 & 1.765933 & 1.054377 \\
\hline 3 & 6 & 0 & 1.063767 & -0.571396 & 0.892032 \\
\hline 4 & 6 & 0 & -0.265982 & -0.109976 & 0.629443 \\
\hline 5 & 1 & $\odot$ & 1.105709 & 1.480657 & 2.090012 \\
\hline 6 & 1 & $\odot$ & 1.564310 & 2.617238 & ๑.708632 \\
\hline 7 & 1 & $\odot$ & 1.277347 & -1.355365 & 1.616605 \\
\hline 8 & 6 & 0 & 2.113627 & -0.378686 & -0.139701 \\
\hline 9 & 8 & 0 & 1.957202 & ๑.018581 & -1.288138 \\
\hline 10 & 6 & 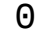 & -1.483346 & -0.785007 & $\odot .511362$ \\
\hline 11 & 6 & $\odot$ & -1.147203 & 1.944510 & -0.404264 \\
\hline 12 & 1 & 0 & -1.032484 & 2.973772 & -0.723172 \\
\hline 13 & 6 & $\odot$ & 9953 & 74674 & 3650 \\
\hline
\end{tabular}




\begin{tabular}{|c|c|c|c|c|c|}
\hline 14 & 6 & $\odot$ & -2.329507 & 1.248585 & -0.617494 \\
\hline 15 & 8 & $\odot$ & 3.311738 & -0.805224 & ๑. 352934 \\
\hline 16 & 6 & $\odot$ & 4.401069 & -0.726839 & -0.591865 \\
\hline 17 & 1 & $\odot$ & 4.562590 & $\odot .305550$ & -0.894537 \\
\hline 18 & 1 & $\odot$ & 4.183343 & -1.331870 & -1.468846 \\
\hline 19 & 1 & $\odot$ & 5.262311 & -1.112473 & -0.057167 \\
\hline 20 & 1 & $\odot$ & -1.624140 & -1.825734 & $\odot .779563$ \\
\hline 21 & 7 & $\odot$ & -3.799837 & $-\odot .631281$ & -0.411815 \\
\hline 22 & 8 & $\odot$ & -3.961922 & -1.793709 & ๑.0๑7116 \\
\hline 23 & 1 & $\odot$ & -3.162251 & 1.702254 & -1.141900 \\
\hline
\end{tabular}

TS for $\mathbf{7} \rightarrow \mathbf{8}, \mathrm{R}=\mathrm{NO}^{\mathrm{a}} \quad(\mathrm{G}=-664.729434$ Hartrees $)$

\begin{tabular}{|c|c|c|c|c|c|}
\hline 1 & 6 & $\odot$ & $\odot .729222$ & 1.746589 & ๑. 084366 \\
\hline 2 & 6 & $\odot$ & $-\odot .363439$ & 2.585634 & $\odot .450306$ \\
\hline 3 & 6 & $\odot$ & -1.188072 & ๑. 620104 & -0.421279 \\
\hline 4 & 6 & $\odot$ & 0.199934 & $\odot .436064$ & -0.091859 \\
\hline 5 & 1 & $\odot$ & -0.408529 & 3.644376 & $\odot .203670$ \\
\hline 6 & 1 & $\odot$ & $-\odot .992880$ & 2.257226 & 1.266378 \\
\hline 7 & 1 & $\odot$ & -1.425772 & 1.259274 & -1.261846 \\
\hline 8 & 6 & $\odot$ & -2.226909 & $-\odot .323717$ & ๑. 023698 \\
\hline 9 & 8 & $\odot$ & -2.029428 & -1.275735 & 0.775115 \\
\hline 10 & 6 & 0 & 1.016399 & $-\odot .695537$ & -0.024036 \\
\hline 11 & 6 & $\odot$ & 2.108110 & 1.991141 & -0.076834 \\
\hline 12 & 1 & $\odot$ & 2.520142 & 2.993482 & $-\odot .060660$ \\
\hline 13 & 6 & $\odot$ & 2.392245 & -0.436944 & $-\odot .047527$ \\
\hline 14 & 6 & $\odot$ & 2.931728 & $\odot .871755$ & -0.105983 \\
\hline 15 & 8 & $\odot$ & -3.440449 & $-\odot . \odot \odot 4559$ & -0.494445 \\
\hline 16 & 6 & $\odot$ & -4.512373 & -0.883637 & -0.083997 \\
\hline 17 & 1 & $\odot$ & -4.609228 & -0.874928 & $\odot .999250$ \\
\hline 18 & 1 & $\odot$ & -4.314499 & -1.897582 & -0.423487 \\
\hline 19 & 1 & $\odot$ & -5.400368 & $-\odot .480862$ & -0.558219 \\
\hline 20 & 1 & $\odot$ & $\odot .637930$ & -1.709295 & -0.052452 \\
\hline 21 & 7 & $\odot$ & 3. 392351 & -1.475073 & $-\odot .055758$ \\
\hline 22 & 8 & $\odot$ & 2.934349 & -2.632663 & $-\odot .0 \odot 6505$ \\
\hline 23 & 1 & $\odot$ & 4.009904 & ๑. 968766 & -0.156775 \\
\hline
\end{tabular}

TS for $\mathbf{7} \rightarrow \mathbf{9}, \mathrm{R}=\mathrm{NO}^{\mathrm{b}} \quad(\mathrm{G}=-664.726777$ Hartrees $)$

\begin{tabular}{|c|c|c|c|c|c|}
\hline 1 & 6 & $\odot$ & -0.184357 & 1.193231 & $\odot .338750$ \\
\hline 2 & 6 & $\odot$ & $\odot .965560$ & 1.799512 & ๑. 915910 \\
\hline 3 & 6 & $\odot$ & 1.203953 & -0.511230 & ๑.957356 \\
\hline 4 & 6 & $\odot$ & -0.167615 & -0.175205 & 0.721926 \\
\hline 5 & 1 & $\odot$ & 1.148120 & 1.632343 & 1.968491 \\
\hline 6 & 1 & $\odot$ & 1.478686 & 2.644206 & $\odot .460953$ \\
\hline 7 & 1 & $\odot$ & 1.510302 & -1.206392 & 1.737386 \\
\hline 8 & 6 & $\odot$ & 2.188980 & -0.347306 & -0.142521 \\
\hline 9 & 8 & $\odot$ & 1.953204 & $-\odot .065961$ & -1.311212 \\
\hline 10 & 6 & $\odot$ & -1.344984 & -0.933214 & 0.717225 \\
\hline 11 & 6 & $\odot$ & -1.251066 & 1.714269 & -0.428621 \\
\hline 12 & 1 & $\odot$ & -1.222212 & 2.718684 & -0.835149 \\
\hline 13 & 6 & $\odot$ & -2.438535 & $-\odot .356525$ & $\odot .066485$ \\
\hline 14 & 6 & $\odot$ & -2.392298 & 0.934234 & -0.526609 \\
\hline 15 & 8 & $\odot$ & 3.434596 & $-\odot .650 \odot 26$ & $\odot .322734$ \\
\hline
\end{tabular}




$\begin{array}{rrrrrr}16 & 6 & \odot & 4.472014 & -0.586788 & -0.679992 \\ 17 & 1 & 0 & 4.547412 & -.422200 & -1.079666 \\ 18 & 1 & \odot & 4.257343 & -1.281849 & -1.488274 \\ 19 & 1 & 0 & 5.381271 & -0.865339 & -0.158472 \\ 20 & 1 & 0 & -1.411475 & -1.953057 & 1.080716 \\ 21 & 7 & 0 & -3.601480 & -1.199419 & 0.029249 \\ 22 & 8 & 0 & -4.577163 & -0.708186 & -0.572537 \\ 23 & 1 & \odot & -3.274089 & 1.292647 & -1.042073\end{array}$

TS for $\mathbf{7} \rightarrow \mathbf{8}, \mathrm{R}=\mathrm{NO}^{\mathrm{b}} \quad(\mathrm{G}=-664.730070$ Hartrees $)$

\begin{tabular}{|c|c|c|c|c|c|}
\hline 1 & 6 & $\odot$ & $\odot .641508$ & 1.640648 & ๑. 082283 \\
\hline 2 & 6 & $\odot$ & -0.449221 & 2.493499 & $\odot .428143$ \\
\hline 3 & 6 & $\odot$ & -1.287479 & ๑.550831 & -0.430410 \\
\hline 4 & 6 & $\odot$ & ๑. 095665 & ๑. 342813 & $-\odot .095676$ \\
\hline 5 & 1 & $\odot$ & $-\odot .484994$ & 3.549104 & ๑.165924 \\
\hline 6 & 1 & $\odot$ & -1.081492 & 2.185583 & 1.250008 \\
\hline 7 & 1 & $\odot$ & -1.511851 & 1.182919 & -1.279891 \\
\hline 8 & 6 & $\odot$ & -2.342966 & -0.374197 & ๑.017843 \\
\hline 9 & 8 & $\odot$ & -2.158370 & -1.331433 & 0.765704 \\
\hline 10 & 6 & $\odot$ & $\odot .907280$ & -0.795664 & -0.015765 \\
\hline 11 & 6 & $\odot$ & 2.029675 & 1.865261 & -0.057526 \\
\hline 12 & 1 & $\odot$ & 2.451089 & 2.863971 & -0.037127 \\
\hline 13 & 6 & $\odot$ & 2.284968 & -0.558992 & -0.028719 \\
\hline 14 & 6 & $\odot$ & 2.846680 & 0.744251 & $-\odot .076953$ \\
\hline 15 & 8 & $\odot$ & -3.552779 & $-\odot .031028$ & -0.492208 \\
\hline 16 & 6 & $\odot$ & -4.639180 & $-\odot .890186$ & -0.077116 \\
\hline 17 & 1 & $\odot$ & -4.728515 & $-\odot .882805$ & 1.006761 \\
\hline 18 & 1 & $\odot$ & -4.463465 & -1.906703 & -0.421000 \\
\hline 19 & 1 & $\odot$ & -5.522161 & -0.468545 & -0.544204 \\
\hline 20 & 1 & $\odot$ & ๑.526205 & -1.809457 & $-\odot .037851$ \\
\hline 21 & 7 & $\odot$ & 3.081035 & -1.756103 & $-0.01690 \odot$ \\
\hline 22 & 8 & $\odot$ & 4.311377 & -1.558571 & $-\odot .066741$ \\
\hline 23 & 1 & $\odot$ & 3.924529 & 0.837318 & -0.114987 \\
\hline
\end{tabular}

TS for $\mathbf{7 \rightarrow 9}, R=\mathrm{COMe}^{\mathrm{a}} \quad(\mathrm{G}=-687.934058$ Hartrees $)$

$\begin{array}{rrrrrr}1 & 6 & 0 & -0.265324 & 1.300569 & -0.468598 \\ 2 & 6 & 0 & -1.465427 & 1.741617 & -1.091886 \\ 3 & 6 & 0 & -1.489210 & -0.586242 & -0.882941 \\ 4 & 6 & 0 & -0.155428 & -0.097579 & -0.703065 \\ 5 & 1 & 0 & -1.638547 & 1.445422 & -2.117208 \\ 6 & 1 & 0 & -2.046476 & 2.584594 & -0.723434 \\ 7 & 1 & 0 & -1.728032 & -1.391516 & -1.575724 \\ 8 & 6 & 0 & -2.485565 & -0.388229 & 0.198030 \\ 9 & 8 & 0 & -2.278244 & 0.030441 & 1.331147 \\ 10 & 6 & 0 & 1.081317 & -0.747039 & -0.634761 \\ 11 & 6 & 0 & 0.753335 & 1.981426 & 0.225218 \\ 12 & 1 & 0 & 0.649987 & 3.018416 & 0.523737 \\ 13 & 6 & 0 & 2.139786 & -0.032833 & -0.060097 \\ 14 & 6 & 0 & 1.956006 & 1.303878 & 0.392328 \\ 15 & 8 & 0 & -3.703581 & -0.839921 & -0.223295 \\ 16 & 6 & 0 & -4.740965 & -0.760296 & 0.776755 \\ 17 & 1 & 0 & -4.901516 & 0.274626 & 1.071633\end{array}$




$\begin{array}{rrrrrr}18 & 1 & \odot & -4.468754 & -1.347350 & 1.650879 \\ 19 & 1 & \odot & -5.624416 & -1.166373 & \odot .295813 \\ 20 & 1 & \odot & 1.219894 & -1.789117 & -\Theta .899511 \\ 21 & 6 & \odot & 3.454276 & -0.735241 & 0.088474 \\ 22 & 1 & \odot & 2.779658 & 1.820665 & 0.868209 \\ 23 & 8 & \odot & 3.623633 & -1.854461 & -\odot .407081 \\ 24 & 6 & \odot & 4.566995 & -\odot .057376 & \odot .855803 \\ 25 & 1 & \odot & 4.858483 & 0.873770 & 0.367748 \\ 26 & 1 & \odot & 4.246346 & 0.182005 & 1.870398 \\ 27 & 1 & \odot & 5.420134 & -\odot .729541 & 0.889737\end{array}$

TS for $\mathbf{7 \rightarrow \mathbf { 8 }}, \mathrm{R}=\mathrm{COMe}^{\mathrm{a}}(\mathrm{G}=-687.936622$ Hartrees $)$

\begin{tabular}{|c|c|c|c|c|c|}
\hline 1 & 6 & $\odot$ & 0.174525 & 1.903072 & $\odot .063782$ \\
\hline 2 & 6 & $\odot$ & -0.996141 & 2.637382 & $\odot .419750$ \\
\hline 3 & 6 & $\odot$ & -1.623186 & $\odot .591327$ & -0.422417 \\
\hline 4 & 6 & $\odot$ & $-\odot .221731$ & ๑.549091 & -0.099274 \\
\hline 5 & 1 & $\odot$ & -1.144249 & 3.683218 & $\odot .157506$ \\
\hline 6 & 1 & $\odot$ & -1.586726 & 2.264589 & 1.245603 \\
\hline 7 & 1 & $\odot$ & -1.926455 & 1.190372 & -1.271320 \\
\hline 8 & 6 & $\odot$ & -2.564564 & $-\odot .440233$ & ๑. 042442 \\
\hline 9 & 8 & $\odot$ & -2.285389 & -1.339848 & $\odot .831440$ \\
\hline 10 & 6 & 0 & $\odot .707208$ & $-\odot .493437$ & $-\odot .026229$ \\
\hline 11 & 6 & 0 & 1.524830 & 2.268339 & $-\odot .093540$ \\
\hline 12 & 1 & $\odot$ & 1.845466 & 3.304096 & $-\odot .085537$ \\
\hline 13 & 6 & $\odot$ & 2.061648 & -0.133498 & -0.051106 \\
\hline 14 & 6 & $\odot$ & 2.453563 & 1.231470 & -0.114492 \\
\hline 15 & 8 & $\odot$ & -3.798141 & -0.266635 & -0.501770 \\
\hline 16 & 6 & $\odot$ & -4.778713 & -1.236313 & -0.070430 \\
\hline 17 & 1 & $\odot$ & -4.892183 & -1.199191 & 1.010720 \\
\hline 18 & 1 & $\odot$ & -4.472792 & -2.236237 & -0.369205 \\
\hline 19 & 1 & $\odot$ & -5.696974 & $-\odot .945668$ & -0.568714 \\
\hline 20 & 1 & $\odot$ & $\odot .423881$ & -1.538249 & $-\odot .043705$ \\
\hline 21 & 6 & $\odot$ & 3.076592 & -1.235262 & -0.045216 \\
\hline 22 & 1 & $\odot$ & 3.505704 & 1.480542 & -0.171190 \\
\hline 23 & 8 & $\odot$ & 2.723144 & -2.414374 & -0.149409 \\
\hline 24 & 6 & $\odot$ & 4.540291 & -0.882531 & $\odot .103735$ \\
\hline 25 & 1 & $\odot$ & 4.883420 & $-\odot .299667$ & $-\odot .752396$ \\
\hline 26 & 1 & $\odot$ & 4.706744 & $-\odot .288066$ & $1.0 \odot 2769$ \\
\hline 27 & 1 & $\odot$ & 5.111316 & -1.805320 & $\odot .161370$ \\
\hline
\end{tabular}

TS for $\mathbf{7 \rightarrow 9}, R=\operatorname{COMe}^{b} \quad(G=-687.934614$ Hartrees $)$

\begin{tabular}{|c|c|c|c|c|c|}
\hline 1 & 6 & $\odot$ & $\odot .270653$ & 1.329102 & $\odot .449889$ \\
\hline 2 & 6 & $\odot$ & 1.472916 & 1.731995 & 1.096349 \\
\hline 3 & 6 & $\odot$ & 1.443497 & $-\odot .584924$ & ๑.875138 \\
\hline 4 & 6 & $\odot$ & $\odot .125059$ & -0.066032 & $\odot .670024$ \\
\hline 5 & 1 & $\odot$ & 1.617292 & 1.431150 & 2.124761 \\
\hline 6 & 1 & $\odot$ & 2.082839 & 2.560829 & 0.742450 \\
\hline 7 & 1 & $\odot$ & 1.650663 & -1.397432 & 1.570158 \\
\hline 8 & 6 & $\odot$ & 2.467531 & -0.408299 & $-\odot .183743$ \\
\hline 9 & 8 & $\odot$ & 2.294410 & ๑.015709 & -1.320234 \\
\hline 10 & 6 & $\odot$ & -1.127851 & $-\odot .686732$ & $\odot .571523$ \\
\hline 11 & 6 & $\odot$ & -0.722331 & 2.043430 & -0.251663 \\
\hline
\end{tabular}




\begin{tabular}{|c|c|c|c|c|c|}
\hline 12 & 1 & $\odot$ & -0.587319 & 3.079942 & $-\odot .538926$ \\
\hline 13 & 6 & $\odot$ & -2.159639 & $\odot .061235$ & $-\odot . \odot \odot 9 \odot 95$ \\
\hline 14 & 6 & $\odot$ & -1.937560 & 1.400606 & -0.437636 \\
\hline 15 & 8 & $\odot$ & 3.665834 & $-\odot .887109$ & 0.264113 \\
\hline 16 & 6 & $\odot$ & 4.727837 & -0.824576 & -0.711295 \\
\hline 17 & 1 & $\odot$ & 4.915630 & ๑. 208014 & $-\odot .997974$ \\
\hline 18 & 1 & $\odot$ & 4.464610 & -1.402744 & -1.594042 \\
\hline 19 & 1 & $\odot$ & 5.591564 & -1.249895 & -0.211542 \\
\hline 20 & 1 & $\odot$ & -1.256122 & -1.732776 & ๑. 824768 \\
\hline 21 & 6 & $\odot$ & -3.521563 & -0.519395 & -0.220672 \\
\hline 22 & 1 & $\odot$ & -2.766074 & 1.914980 & -0.908143 \\
\hline 23 & 8 & $\odot$ & -4.415751 & 0.152376 & -0.747157 \\
\hline 24 & 6 & $\odot$ & -3.788627 & -1.941033 & ๑. 222573 \\
\hline 25 & 1 & $\odot$ & -3.156128 & -2.639443 & -0.327349 \\
\hline 26 & 1 & $\odot$ & -3.579519 & -2.062947 & 1.285898 \\
\hline 27 & 1 & $\odot$ & -4.832916 & -2.169743 & ๑. 027814 \\
\hline
\end{tabular}

TS for $\mathbf{7 \rightarrow \mathbf { 8 }}, \mathrm{R}=\mathrm{COMe}^{\mathrm{b}} \quad(\mathrm{G}=-687.938384$ Hartrees $)$

\begin{tabular}{|c|c|c|c|c|c|}
\hline 1 & 6 & $\odot$ & 0.181639 & 1.938760 & ๑. 099291 \\
\hline 2 & 6 & $\odot$ & -1.009661 & 2.639571 & $\odot .460689$ \\
\hline 3 & 6 & 0 & -1.592943 & 0.617832 & -0.425004 \\
\hline 4 & 6 & 0 & -0.192283 & 0.585619 & $-\odot .09867 \odot$ \\
\hline 5 & 1 & 0 & -1.181315 & 3.685649 & ๑. 213256 \\
\hline 6 & 1 & 0 & -1.588439 & 2. 246294 & 1.285486 \\
\hline 7 & 1 & $\odot$ & -1.905406 & 1.231294 & -1.259995 \\
\hline 8 & 6 & $\odot$ & -2.514041 & -0.448592 & $\odot .0 \odot 1507$ \\
\hline 9 & 8 & $\odot$ & -2.199605 & -1.403850 & ๑.708911 \\
\hline 10 & 6 & 0 & 0.753402 & -0.446353 & -0.036616 \\
\hline 11 & 6 & 0 & 1.529033 & 2. 329712 & -0.037625 \\
\hline 12 & 1 & $\odot$ & 1.832223 & 3.369989 & $\odot .001316$ \\
\hline 13 & 6 & $\odot$ & 2.101106 & $-\odot .062676$ & -0.043265 \\
\hline 14 & 6 & $\odot$ & 2.471728 & 1.309936 & -0.073929 \\
\hline 15 & 8 & $\odot$ & -3.767908 & -0.244826 & -0.478800 \\
\hline 16 & 6 & $\odot$ & -4.728618 & -1.248606 & -0.081559 \\
\hline 17 & 1 & 0 & -4.797163 & -1.293195 & 1.003002 \\
\hline 18 & 1 & $\odot$ & -4.434311 & -2.221826 & -0.467483 \\
\hline 19 & 1 & $\odot$ & -5.666997 & $-\odot .925175$ & -0.518226 \\
\hline 20 & 1 & $\odot$ & 0.448366 & -1.483783 & -0.076002 \\
\hline 21 & 6 & $\odot$ & 3.198589 & -1.078981 & -0.043870 \\
\hline 22 & 1 & 0 & 3.529382 & 1.539492 & -0.111277 \\
\hline 23 & 8 & 0 & 4.378973 & -0.729208 & -0.158029 \\
\hline 24 & 6 & $\odot$ & 2.838542 & -2.540395 & 0.103438 \\
\hline 25 & 1 & 0 & 2.242515 & -2.706390 & 1.001257 \\
\hline 26 & 1 & 0 & 2.252461 & -2.877372 & -0.753003 \\
\hline 27 & 1 & $\odot$ & 3.758056 & -3.116878 & ๑. 158681 \\
\hline
\end{tabular}

TS for $\mathbf{7} \rightarrow \mathbf{9}, \mathrm{R}=\mathrm{CHO}^{\mathrm{a}}(\mathrm{G}=-648.767703$ Hartrees $)$

$\begin{array}{rrrrrr}1 & 6 & 0 & -\odot .130938 & 1.298133 & \odot .369994 \\ 2 & 6 & 0 & 1.029201 & 1.760365 & 1.049450 \\ 3 & 6 & 0 & 1.078935 & -0.574361 & 0.888520 \\ 4 & 6 & 0 & -0.245476 & -0.097608 & 0.629305 \\ 5 & 1 & 0 & 1.150028 & 1.480976 & 2.086938\end{array}$




\begin{tabular}{|c|c|c|c|c|c|}
\hline 6 & 1 & $\odot$ & 1.622740 & 2.601787 & 0.698120 \\
\hline 7 & 1 & $\odot$ & 1.285066 & -1.363585 & 1.609581 \\
\hline 8 & 6 & $\odot$ & 2.129606 & -0.391165 & -0.143329 \\
\hline 9 & 8 & $\odot$ & 1.978467 & 0.006747 & -1.292505 \\
\hline 10 & 6 & $\odot$ & -1.475177 & $-\odot .753763$ & ๑. 515551 \\
\hline 11 & 6 & $\odot$ & -1.110649 & 1.964397 & -0.392904 \\
\hline 12 & 1 & $\odot$ & -0.989193 & 2.993663 & -0.710171 \\
\hline 13 & 6 & $\odot$ & -2.497396 & -0.045222 & -0.126035 \\
\hline 14 & 6 & $\odot$ & -2.300684 & 1.278196 & $-0.6 \odot 2880$ \\
\hline 15 & 8 & $\odot$ & 3.324897 & -0.829543 & 0.348621 \\
\hline 16 & 6 & $\odot$ & 4.413143 & $-\odot .762864$ & -0.597434 \\
\hline 17 & 1 & $\odot$ & 4.584939 & $\odot .267497$ & -0.901621 \\
\hline 18 & 1 & $\odot$ & 4.188629 & -1.366402 & -1.473816 \\
\hline 19 & 1 & $\odot$ & 5.271521 & -1.156535 & $-\odot .063804$ \\
\hline 20 & 1 & $\odot$ & -1.627454 & -1.791341 & 0.792585 \\
\hline 21 & 6 & $\odot$ & -3.807523 & -0.694310 & -0.355800 \\
\hline 22 & 1 & $\odot$ & -3.115060 & 1.764900 & -1.130071 \\
\hline 23 & 8 & $\odot$ & -4.093157 & -1.832089 & 0.016805 \\
\hline 24 & 1 & $\odot$ & -4.551116 & $-\odot .082672$ & -0.897734 \\
\hline
\end{tabular}

TS for $\mathbf{7} \rightarrow \mathbf{8}, \mathrm{R}=\mathrm{CHO}^{\mathrm{a}} \quad(\mathrm{G}=-648.770584$ Hartrees $)$

\begin{tabular}{|c|c|c|c|c|c|}
\hline 1 & 6 & $\odot$ & 0.681752 & 1.776425 & ๑. 079595 \\
\hline 2 & 6 & $\odot$ & $-\odot .426728$ & 2.598486 & $\odot .440194$ \\
\hline 3 & 6 & $\odot$ & -1.213663 & $\odot .614257$ & -0.421648 \\
\hline 4 & 6 & $\odot$ & $\odot .177516$ & $\odot .457477$ & -0.092491 \\
\hline 5 & 1 & $\odot$ & -0.490157 & 3.655019 & $\odot .187402$ \\
\hline 6 & 1 & $\odot$ & -1.048998 & 2.265093 & 1.259625 \\
\hline 7 & 1 & $\odot$ & -1.463939 & 1. 245084 & -1.264809 \\
\hline 8 & $\overline{6}$ & $\odot$ & -2.235987 & -0.344522 & $\odot .028512$ \\
\hline 9 & 8 & $\odot$ & -2.027823 & -1.279349 & 0.798245 \\
\hline 10 & 6 & $\odot$ & 1.019577 & -0.656481 & -0.018139 \\
\hline 11 & 6 & $\odot$ & 2.056501 & 2.041606 & -0.075544 \\
\hline 12 & 1 & $\odot$ & 2.453149 & 3.050434 & -0.060102 \\
\hline 13 & 6 & $\odot$ & 2.394723 & -0.390703 & -0.040836 \\
\hline 14 & 6 & $\odot$ & 2.898538 & $\odot .934419$ & -0.100768 \\
\hline 15 & 8 & $\odot$ & -3.451995 & -0.059555 & -0.506332 \\
\hline 16 & 6 & $\odot$ & -4.508303 & -0.953517 & -0.089253 \\
\hline 17 & 1 & $\odot$ & -4.615583 & -0.927344 & $\odot .992797$ \\
\hline 18 & 1 & $\odot$ & -4.286052 & -1.969237 & -0.407866 \\
\hline 19 & 1 & $\odot$ & -5.400529 & -0.578887 & -0.578555 \\
\hline 20 & 1 & $\odot$ & $\odot .657651$ & -1.677233 & -0.037979 \\
\hline 21 & 6 & $\odot$ & 3.362064 & -1.511475 & -0.045740 \\
\hline 22 & 1 & $\odot$ & 3.973047 & 1.079181 & -0.153211 \\
\hline 23 & 8 & $\odot$ & 3.049644 & -2.701370 & -0.023128 \\
\hline 24 & 1 & $\odot$ & 4.426860 & -1.215756 & $-\odot .070875$ \\
\hline
\end{tabular}

TS for $\mathbf{7} \rightarrow \mathbf{9}, \mathrm{R}=\mathrm{CHO}^{\mathrm{b}} \quad(\mathrm{G}=-648.768213$ Hartrees $)$

$\begin{array}{rrrrrr}1 & 6 & 0 & 0.151948 & 1.203569 & -0.343201 \\ 2 & 6 & \odot & -1.006963 & 1.791613 & -0.922894 \\ 3 & 6 & 0 & -1.214913 & -0.525492 & -0.945605 \\ 4 & 6 & 0 & 0.151331 & -0.168321 & -0.713489\end{array}$




\begin{tabular}{|c|c|c|c|c|c|}
\hline 5 & 1 & $\odot$ & -1.188612 & 1.616161 & -1.974199 \\
\hline 6 & 1 & $\odot$ & -1.527608 & 2.634796 & -0.473416 \\
\hline 7 & 1 & $\odot$ & -1.511358 & -1.234074 & -1.717551 \\
\hline 8 & 6 & $\odot$ & -2.204595 & -0.359950 & 0.148397 \\
\hline 9 & 8 & $\odot$ & -1.976340 & $-\odot .072504$ & 1.317277 \\
\hline 10 & 6 & $\odot$ & 1.339423 & $-\odot .911507$ & -0.704363 \\
\hline 11 & 6 & $\odot$ & 1.214732 & 1.741538 & 0.414427 \\
\hline 12 & 1 & $\odot$ & 1.179260 & 2.749205 & 0.812318 \\
\hline 13 & 6 & $\odot$ & 2.437644 & -0.327470 & -0.065448 \\
\hline 14 & 6 & $\odot$ & 2.362869 & ๑.969644 & ๑.512960 \\
\hline 15 & 8 & $\odot$ & -3.448262 & $-\odot .672009$ & -0.319685 \\
\hline 16 & 6 & $\odot$ & -4.488599 & -0.606833 & 0.679152 \\
\hline 17 & 1 & $\odot$ & -4.569981 & 0.404320 & 1.072278 \\
\hline 18 & 1 & $\odot$ & -4.273919 & -1.295432 & 1.493048 \\
\hline 19 & 1 & $\odot$ & -5.395319 & $-\odot .892656$ & 0.156951 \\
\hline 20 & 1 & $\odot$ & 1.387716 & -1.934141 & -1.068047 \\
\hline 21 & 6 & $\odot$ & 3.693927 & -1.100276 & 0.029281 \\
\hline 22 & 1 & $\odot$ & 3.242082 & 1.344187 & 1.023268 \\
\hline 23 & 8 & $\odot$ & 4.720983 & -0.696770 & 0.574772 \\
\hline 24 & 1 & $\odot$ & 3.665868 & -2.101201 & -0.438867 \\
\hline
\end{tabular}

TS for $\mathbf{7} \rightarrow \mathbf{8}, \mathrm{R}=\mathrm{CHO}^{\mathrm{b}} \quad(\mathrm{G}=-648.771944$ Hartrees $)$

\begin{tabular}{|c|c|c|c|c|c|}
\hline 1 & 6 & 0 & 0.603554 & 1.672515 & 0.081226 \\
\hline 2 & 6 & 0 & -0.501298 & 2.506847 & ๑. 431621 \\
\hline 3 & 6 & 0 & -1.308573 & ๑.552494 & -0.430244 \\
\hline 4 & 6 & $\odot$ & ๑.078534 & $\odot .366854$ & $-\odot .099889$ \\
\hline 5 & 1 & 0 & -0.554676 & 3.562340 & 0.171230 \\
\hline 6 & 1 & 0 & -1.123066 & 2.189526 & 1.257848 \\
\hline 7 & 1 & 0 & -1.548022 & 1.186960 & -1.273691 \\
\hline 8 & 6 & 0 & -2.345330 & -0.396405 & $\odot .0 \odot 9755$ \\
\hline 9 & 8 & $\odot$ & -2.139668 & -1.371310 & $\odot .729647$ \\
\hline 10 & 6 & $\odot$ & $\odot .90879 \odot$ & -0.759043 & -0.021258 \\
\hline 11 & 6 & 0 & 1.986717 & 1.915688 & -0.057931 \\
\hline 12 & 1 & 0 & 2.396765 & 2.919068 & -0.034453 \\
\hline 13 & 6 & 0 & 2.286823 & -0.516257 & -0.030693 \\
\hline 14 & 6 & 0 & 2.815499 & ๑. 801622 & -0.079353 \\
\hline 15 & 8 & 0 & -3.567549 & $-\odot .056686$ & -0.473660 \\
\hline 16 & 6 & 0 & -4.636584 & -0.939047 & -0.063833 \\
\hline 17 & 1 & 0 & -4.710408 & -0.958810 & 1.021087 \\
\hline 18 & 1 & 0 & -4.453807 & -1.944972 & -0.434343 \\
\hline 19 & 1 & $\odot$ & -5.531692 & -0.517860 & $-\odot .507804$ \\
\hline 20 & 1 & 0 & 0.514250 & -1.769206 & -0.042994 \\
\hline 21 & 6 & 0 & 3.207729 & -1.672617 & -0.016778 \\
\hline 22 & 1 & 0 & 3.892661 & ๑. 911842 & -0.117990 \\
\hline 23 & 8 & 0 & 4.435297 & -1.586141 & $-\odot .057407$ \\
\hline 24 & 1 & 0 & 2.718194 & -2.661691 & 0.036736 \\
\hline
\end{tabular}

TS for $\mathbf{7} \rightarrow \mathbf{9}, \mathrm{R}=\mathrm{NO}_{2} \quad(\mathrm{G}=-739.756559$ Hartrees $)$

$\begin{array}{rrrrrr}1 & 6 & 0 & -0.207504 & 1.293758 & -0.463711 \\ 2 & 6 & 0 & -1.393333 & 1.732803 & -1.113775 \\ 3 & 6 & 0 & -1.432306 & -0.592450 & -0.879710 \\ 4 & 6 & 0 & -0.100884 & -0.107078 & -0.681272\end{array}$




\begin{tabular}{|c|c|c|c|c|c|}
\hline 5 & 1 & $\odot$ & -1.550451 & 1.424453 & -2.137990 \\
\hline 6 & 1 & $\odot$ & -1.980874 & 2.577963 & $-\odot .761910$ \\
\hline 7 & 1 & $\odot$ & -1.659802 & -1.406348 & -1.565938 \\
\hline 8 & 6 & $\odot$ & -2.446653 & -0.379465 & ๑.183899 \\
\hline 9 & 8 & $\odot$ & -2.257007 & ๑.066400 & 1.309345 \\
\hline 10 & 6 & $\odot$ & 1.132568 & $-\odot .765301$ & -0.590709 \\
\hline 11 & 6 & $\odot$ & ๑.801454 & 1.983479 & ๑. 238394 \\
\hline 12 & 1 & $\odot$ & $\odot .693912$ & 3.023120 & 0.524191 \\
\hline 13 & 6 & $\odot$ & 2.152518 & -0.017624 & -0.012913 \\
\hline 14 & 6 & $\odot$ & 2.003480 & 1.315419 & 0.433621 \\
\hline 15 & 8 & $\odot$ & -3.651994 & -0.849492 & -0.246341 \\
\hline 16 & 6 & $\odot$ & -4.707563 & -0.757447 & 0.735068 \\
\hline 17 & 1 & $\odot$ & -4.880254 & 0.282180 & 1.004876 \\
\hline 18 & 1 & $\odot$ & -4.444563 & -1.324251 & 1.625036 \\
\hline 19 & 1 & $\odot$ & -5.579127 & -1.180633 & 0.247637 \\
\hline 20 & 1 & $\odot$ & 1.276982 & -1.809537 & -0.835553 \\
\hline 21 & 7 & $\odot$ & 3.458235 & -0.665035 & 0.181882 \\
\hline 22 & 8 & $\odot$ & 3.670084 & -1.729052 & -0.429299 \\
\hline 23 & 8 & $\odot$ & 4.271576 & -0.109071 & 0.944482 \\
\hline 24 & 1 & $\odot$ & 2.844594 & 1.801445 & 0.907629 \\
\hline
\end{tabular}

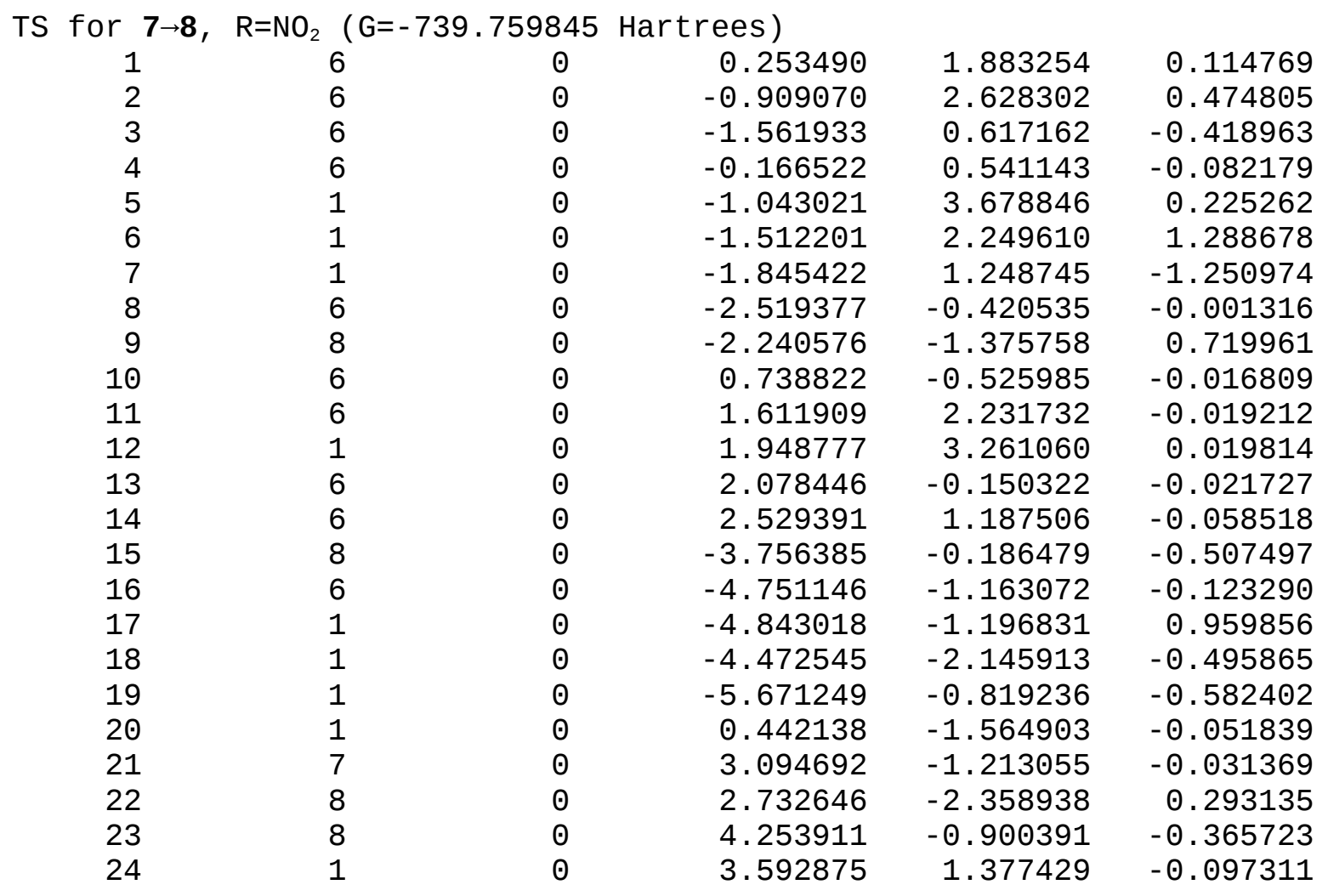


